\title{
ORCHIDS IN ZALA COUNTY (HUNGARY)
}

\author{
Miklós ÓvÁRI \\ H-8900 Zalaegerszeg, Gorkij u.1/d, Hungary; miki58@indamail.hu
}

Óvári, M. (2019): Orchids in Zala County (Hungary). - Studia bot. hung. 50(1): 135-184.

\begin{abstract}
In the present paper, I summarize the results of orchid research of the last three decades in the Southwest Transdanubian region. Besides publishing the detailed occurrences of the orchid taxa recorded, the relevant habitat conditions, as well as the most important environmental changes and threatening factors are also presented.
\end{abstract}

Key words: conservation, ecosystem health indicator, endangered plant, Orchidaceae, Southwest Transdanubian region

\section{INTRODUCTION}

The family of orchids is often overrepresented in botanical research all around Europe: numerous new taxa are being described in the Mediterranean region, and nowadays the orchid flora is considered to be one of the best explored not just in Europe, but all over the World. In most of the European countries, comprehensive orchid atlases are available for the general public; in the last two decades, two such books have also been published in Hungary (Molnár et al. 1995, MOLNÁR 2011).

In the present study, the surveyed area is Zala County and its bordering countryside, which can be found in Transdanubia in southwestern Hungary. This is a geologically and geomorphologically diverse region of the country. In the eastern border of the region, Lake Balaton and the dolomite block of the Keszthely Mts are present; the latter is surrounded by volcanic mountains from the north. In the centre of the area meridional hills can be also found. These hills are mostly built of sandstone, rich in carbonates, and glacial loess accumulated here. In the western part Pannonian sediments are dominant, mostly with acidic soils. North of the Zala Valley, the main substrate of the slopes of Upper Kemeneshát is acidofrequent alluvium of ancient Rába origin.

Accordingly, the vegetation features of the landscape are varied and characterized by high ratio of forest cover. In the east, habitats of dolomite and basalt vegetation are present; whereas in the Eastern Zala Hills, hornbeam and oak forests and Illyrian beech forests grow with alder groves along streams. In the Western Zala Hills mixed deciduous-coniferous woodlands and coniferous 
woodlands are dominant. The greatest river in the region is the Mura, which flows along the state border, while the most dominant river of the region is the Zala River. The most significant lake of the region is Lake Balaton; in addition, the "Small" Balaton (Kis-Balaton), and peat lakes are important habitats here. This varied geological and habitat diversity hosts several orchid taxa in this unique region of the country.

\section{MATERIAL AND METHODS}

My work summarizes the results of field surveys during the last three decades. After pilot studies of the initial period, the research continued with thematic surveys of the region. The field survey was adapted to the three basic natural and semi-natural habitat types of the region: these are the vineyards (including grassland refuge as well as different stages of grassland succession in abandoned vineyard areas), wetlands along streams in the valleys, and zonal forests. Since 2004, data have been recorded using handheld GPS devices. During sampling, a taxon was assigned to the location in a circle of approx. $3 \mathrm{~m}$ diameter, and the phenological status, number of individuals, and exact date of the survey were also recorded.

Descriptive section for each species was sorted by the following theme: microregion - settlement - parcel. Since several settlements were merged in the period after World War II, and several villages were integrated into the towns, it seemed appropriate to indicate the original settlement in these cases. Thus, e.g. in the case of Kemendollár, which was established as a settlement by the unification of Kemend and Ollár settlements. This also seemed to be necessary because of the fact that identical names exist in the case of the parcels in different settlements. The localities are named after the maps of the FÖMI EOV 1: 10,000 scale forestry maps, PAPP \& VÉGH (1964), BALOGH \& ÖRDÖGH (1986) and the 19th century Cadastral Maps of the Habsburg Empire (https://mapire.eu). All records are assigned to microregions, listed from the northwest to the southeast. The abbreviations of microregions - bold highlighted in the enumeration - are the following (Fig. 1): AZv: Lower Zala Valley, ELd: Egerszeg-Letenye Hills, FKh: Upper Kemeneshát, FZv: Upper Zala Valley, G: Göcsej, H: Hetés and Kerka region, Kbm: Kis-Balaton (“Small Balaton”) Basin, Kef: Keszthely Upland, Mh: Marcali Ridge, Mm: Marcal Basin, Ms: Mura Plain, NybS: Western Somogy, PDs: PápaDevecser Plain, Prv: Principális Valley, Tcs: Tátika Group, Tm: Tapolca Basin, Zah: Zalaapáti Ridge, Zvh: Zalavár Ridge.

According to the Hungarian botanical protocol, I also recorded the related CEU grid cell codes (KEF) after enumerating the orchid taxa found (Fig. 2). 
In terms of taxon names, the nomenclature of MOLNÁR (2011) was followed. The specified date of a given habitat represents the first observation (of the population). In addition to my own results, field data of Sándor Palkó (1959-2002) (P. S.), and data of the following informants were also used in this study: László Almádi (1936-2019) (A. L.), Norbert Bauer (B. N.), Olga Baranyai (B. O.), Ágnes Bécsi (B. Á.), Sándor Farkas (F. S.), Zsolt Hóbor (H.Zs.), Tibor Horváth (H. T.), Beatrix Kaszás (K. B.), András Lelkes (L. A.), László Szakács (Sz. L.), Miklós Toldi (T. M.),

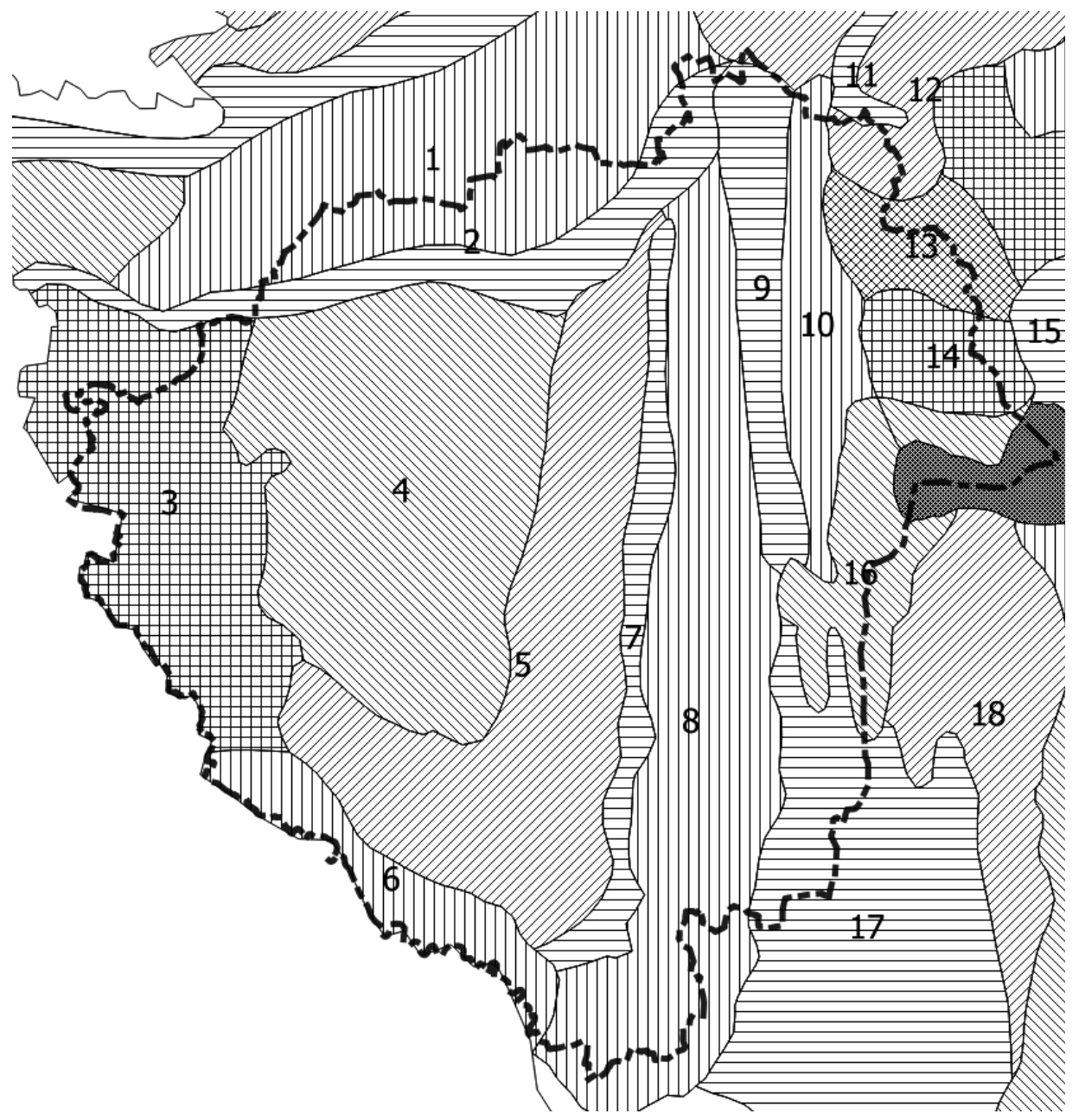

Fig. 1. Location of studied microregions (based on MolNÁr et al. 2008). - 1. Upper Kemeneshát; 2. Upper Zala Valley; 3. Hetés and Kerka region; 4. Göcsej; 5. Egerszeg-Letenye Hills; 6. Mura Plain; 7. Principális Valley; 8. Zalaapáti Ridge; 9. Lower Zala Valley; 10. Zalavár Ridge; 11. Marcal Basin; 12. Pápa-Devecser Plains; 13. Tátika Group; 14. Keszthely Upland; 15. Tapolca Basin; 16. Kis-Balaton (“Small Balaton”) Basin; 17. Western Somogy; 18. Marcali Ridge. 
Róbert Vidéki (V. R.), and the Zala Group of the Hungarian Ornithological and Nature Conservation Society (MME ZHCS) In the case of previous occurrences, during the re-visit of the sites, I have marked $(\dagger)$ the changes that resulted in certain extinctions (grassland plowing, drainage, etc.) of habitats.

The available literature on orchids in the area is rather scarce. In the 18th century, orchid species were included in the flora list of Imre Szenczy, Mihály Hutter, and Péter Wierzbicki (Szenczy et al. 1842). Most of the species indicated by Borbás in the flora of Vas County and the flora of the Balaton, which was published at the end of the 20th century (BORBÁs 1887, 1900), can still be found.

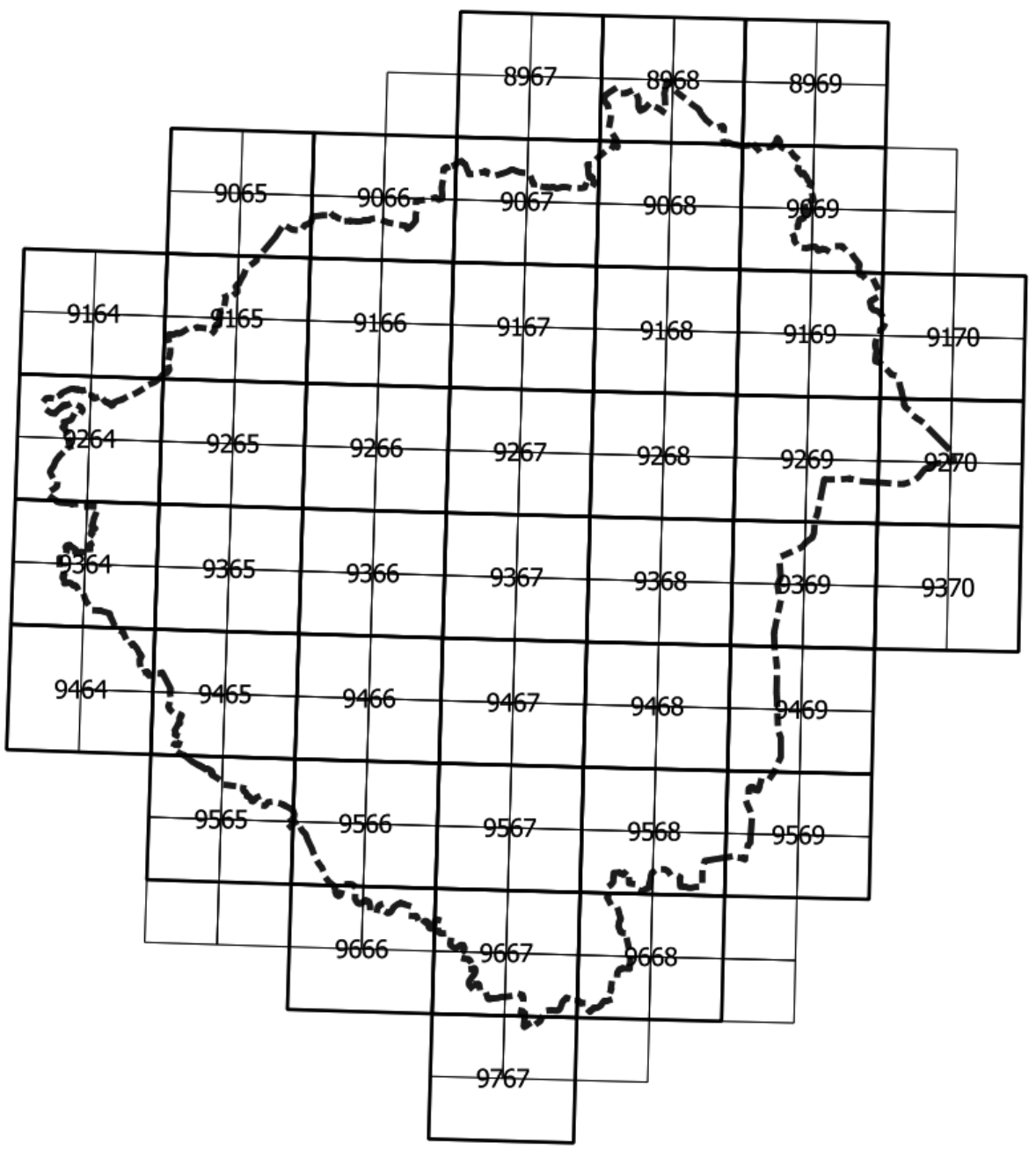

Fig. 2. Distribution of related CEU quarter quadrants in the study area. 
Floristical research by Árpád Károlyi and Tamás Pócs in the last century was released in seven volumes, while orchid data collected by them was only recently published (Kovács 2005).

The orchids of the Keszthely Mts were presented by SzABó (1982), but since then, only few papers discussing single species or flora of single settlements have been published, mainly in graduate theses (BÉCSI 2011, NAGY 2012, GÁL 2006, GÉrUsz 2009).

The presence of some taxa among the species reported in previous publications has not been confirmed. The extremely rare Cypripedium calceolus found by Szenczy et al. has not been found in the past 150 years. The occurrence of Gymnadenia odoratissima collected by Michael Hutter in Keszthely in the same period has certainly not been confirmed; the habitat of the plant probably has been destroyed because of constructing buildings along the shore. Habitats of Spiranthes aestivalis (near Sormás, found by Károlyi) have recently been builtin, and the species has not been found in the sandy area despite the thematic searches. In the pine forests of Göcsej, researchers found Goodyera repens even in the last century (CsAPODY 1982, Soó \& Jávorka 1951, KÁrolyi \& Pócs 1954, 1968), but this species has also disappeared since then.

According to all field surveys, 78 species, subspecies, varieties, and hybrids have been confirmed from the area. The following taxa are new for the flora of Hungary: Epipactis leutei Robatsch, E. helleborine (L.) Crantz subsp. latina W. Rossi \& E. Klein, E. helleborine subsp. moratoria Riech. \& Zirnsack.

Most of the here enumerated records were ceded to use in MOLNÁR (2011).

\section{RESULTS}

Enumeration

\section{Cephalanthera rubra (L.) Rich}

Habitat: beech forests, (sessile) oak-hornbeam forests.

G: Zalaegerszeg: ‘Alsóerdo’’ 2006. Bak: ‘Botosi-erdő’ 2012. Szentpéterfölde: 'Hosszú-hegy' 2012. ELd: Petőhenye: 'Avas-hegy' 1997. Zalaegerszeg-Csács: 'Csácsi-erdő’ 2010. Botfa: 'Bokáncs-erdő’ 2010. Alsónemesapáti: 'Padalja' 2010. Hahót: 'Osztott-erdő' 2016. Oltárc: 'Vár-domb', 2012. Eszteregnye: 'Várbükkierdő', 'Szorosos' 2012. Tormafölde: 'Sárvölgyi-erdő' 1992, 'Vétyemi-ősbükkös' 1994. Murarátka: 'Rátkai-erdő' 1993. Zah: Zalaistvánd: 'Istvándi-erdő', 'Pác-tető' 2014. Padár: 'Padári-felső-erdő', 'András-lap' 2011. Nagykapornak: 'Bánfai-erdő' 2012, 'Remetekert' 2010. Zalacsány: ‘Csányi-erdő' 2010. Nemesrádó: 'Büki-erdő' 2012. Újudvar: 'Dalasi-oldal' 2012. Zvh: Zalaszentlászló: 'Sűrü-bükk' 2010. 
Tcs: Zalaszántó: 'Tátika' 1991. Khg: Rezi: 'Meleg-hegy’ 2005, 'Rezi-vár' 2012, 'Bányafö-tető' 2015, 'Láz-tető' 2010, 'Kis-Cser-völgy', 'Keserü-torony-hegyek', 'Fagyoskereszt', 'Magyar-tető' 2009, 'Kozma-tető' 2011. Vállus: 'Kétfahegyi-tető' 2012, 'Messzi-domb' 2013, 'Büdöskúti-erdő' 2007, 'Iván-hát' 2015, 'Szent-Miklósforrás' 2011, 'Iván-tető' 1992. Gyenesdiás: 'Nyilas-erdő', 'Tüskéslap’ 1997. Balatongyörök: 'Büdöskúti-arborétum' 2013, 'Pad-kői-erdő', 'Boncsos-tető' 2011, 'Keserü-berek' 2016, 'Szobakő-tető' (P. S.) 1992. Lesencefalu: ‘Gesztenyés’ 1991, 2005, 'Kőris-völgy', 'Nyilvány' 2016.

KEF: 9067.4, 9068.2, 9069.4, 9166.4, 9167.2, 9167.3, 9167.4, 9168.1, 9168.2, $9168.3,9169.1,9169.2,9169.3,9169.4,9170.3,9266.3,9268.1,9269.2,9270.1$, 9366.4, 9367.2, 9465.2, 9467.2, 9468.2, 9468.3, 9566.1.

\section{Cephalanthera longifolia (L.) Fritsch}

Habitat: beech forests, (sessile) oak-hornbeam forests, thermophilous oak / Quercus pubescens forests, orchards.

FKh: Zalacséb: 'Román-hegy' 2005. Vaspör: 'Velence-hegyi-erdő' 1998. Zalaszentgyörgy: 'Templom-erdő' 2013. Egervár: ‘Csillag-hegy' 2011. Vasboldogasszony: 'Kövecses' 1990, ‘Csöngeti-erdő' 2000. Gösfa: ‘Bükkös’ 1998. Zalaszentlőrinc: 'Tölgyes-erdő' 1990. Pókaszepetk-Pakod: 'Szepetki-erdő' 2010. H: Magyarföld: 'Berki-hegy' 2008. Rédics-Dedeskecskés: 'Kecskés', 'Kelekút', 'Sándor-gesztenyés' 2005. Lendvadedes: 'Nagyistók-erdő’ 2005. Tornyiszentmiklós: 'Koldustemető' 2008. G: Zalalövő: 'Nyerges' 2011, 'Macskás', 'Laki-erdő' 2009, 2015. Keménfa: 'Kerek-domb’ 2012. Böde: 'Alsó-erdő' 2010. Kálócfa: 'Mihom’, 'Haraszt' 2009. Kustánszeg: 'Kertesi-dűlő'. Milejszeg: 'Gesztenyés' 2010, 'Lókahegy' 2007. Zalaegerszeg: 'Alsóerdő' 1996, 'Bagodi-erdő' 2008, along the road to Gellénház 1988. Szilvágy: 'Kerek-fenyves' 2011, 'Orbán-lap' 2009, 'Felső-erdő' 2000, 'Alsó-erdő' 2015. Bak: 'Felső-erdő' 2018, 'Botosi-erdő' 2008, 'Nénai-erdő' 2009. Lenti-Bárszentmihályfa: 'Zajdai-erdő'2016, ‘Csalános' 1990. Hernyék: 'Szalmahídi-erdő' 2008. Nova: 'Fényesi-hegy' 2013, 'Felső-hegy' 2009, 'Hosszúbránás', 'Lőrincfa-mellék', 'Kondorai-erdő' 2006. Ortaháza: 'Kocsmahegyi-erdő' 1996, 'Bali-erdo’’ 2013. Szentpéterfölde: ‘Szálas-erdő’ 2016, 'Hosszú-hegy’ 2012, 'Kis-berkes' 2003. Pördefölde: 'Pördeföldi-erdő' 2011. Várfölde: 'Községi-erdő' 2012. Zalatárnok-Oroklán: 'Durgó' 2014. Baktüttös: 'Gyertyános' 2009. Pusztaederics: 'Miklós-puszta' 2017. ELd: Kemendollár: 'Bükki-erdő', 'Körtefa-dülő' 2011. Petőhenye: 'Cigány-hegy' 1996, 'Sziácsmány' 2011, 'Alsó-erdő' 2005. Nemesapáti: 'Csertó-hegy’ 2009. Alsónemesapáti: 'Nagy-Újhegy’ 2015, 'Bucsaierdő' 1995. Zalaegerszeg-Csácsbozsok:'Csácsi-erdő' 2006, 'Csácsi-arborétum' 2004. Zalaegerszeg-Botfa: 'Bokáncs' 2010. Kisbucsa: 'Pusztafai-erdő' 2005. Nemeshetés: 'Gesztenyés' 2015. Csatár: 'Pusztika', 'Remete' 2018. Pölöske: 'Edu- 
árd-nyiladék' 2012, 'Béla-tanya-erdő' 2012, 'Nagy-hányási-erdő' 2018, 'Hálásilap’ 2012, 'Benevölgyi-dűlő' 2006, 'Pölöskei-erdő’ 2016, 'Ökör-tilosi-erdő’ 1991. Nemessándorháza: 'Öreg-hegy', 'Kű-hegy' 2008. Nemesrádó: 'Kü-hegy' 2008. Söjtör: 'Nagy-kő-hegy' 2014. Hahót: 'Osztott-erdő' 2016. Bucsuta: 'Büki-erdő' 2012, 'Szekrényesi-oldal' 2008, 'Alsó-erdő' 2009. Bánokszentgyörgy: 'Harasztierdő' 2008. Oltárc: 'Kútfej-erdő', 'Horváti-erdő' 2016. Valkonya: 'Úrbéresierdő' 2011. Eszteregnye-Obornak: 'Várbükki-erdő', 'Szorosa' 2010. Becsehely: 'Barkóczás' 2011. Bázakerettye: roadside verges in the park of the swimming pool 2008. Kistolmács: 'Körvélyes', 'Tolmácsi-erdő' 2010. Zajk: 'Északi-erdő' 2008. Csörnyeföld: 'Vörcsöki-erdő', 'Basai-erdő' 2017. Szentmargitfalva: 'Öreghegy’ 1996. Nagykanizsa: ‘Gördövény’, ‘Hidegkúti-erdő’ 2008. Zah: Zalaistvánd: 'Istvándi-erdő' 2017, 'Pácz-tető' 2014. Bezeréd: 'Felső-erdő' 2012. Padár: 'Hamuházi-tábla' 2011. Ligetfalva: 'Almási-erdő' 1995. Zalacsány: 'Körvélyesierdő' 2010. Nagykapornak: 'Remetekert' 2010, 'Alsó-erdő' 2012. Felsőrajk: 'Törökcsapás' 2007. Gelse: 'Sabján Gyuri-vágás', 'Gelsei-erdő’ 2008. Újudvar: 'Csibit' 1993, 'Korágó’ 2012. Zalamerenye: 'Merenyei-erdő’ 2012, 'Kanicza-erdő' 2000. Nagyrécse: ‘Alsó-erdő’ (F. S.) 2009. Sormás-Nagykanizsa: ‘Gördövény' (H. T.) 2008. Nagykanizsa-Miklósfa: 'Mórichelyi-bükk', 'Gesztenyés' 2009. Szepetnek: 'Csicsa-kunyhó', 'Róka-domb’ (H. T.) 2008. Liszó: 'Lesháti-nyiladék' 2016. Tcs: Nagygörbő: 'Vadlány-barlang' 2016. Zalaszántó: 'Külső-hegy' 2012, 'Tátika' 2016. Khg: Cserszegtomaj: 'Gyötrös' 2011. Rezi: 'Almás-domb' 2012, 'Kozma-tető' 2009, 'Keserü-torony-hegyek' 2011, 'Fagyoskereszt' 2009, 'Láz-tető' 2010, 'Bányafö-tető' 2015, 'Meleg-hegy' 2007, 'Rezi-vár' 2005. Vállus: 'Sárostóiút', 'Büdöskúti-erdő' 2007, 'Büdöskúti-pihenő' 2005, 'Iván-hát' 2009, 'Képestóiputri' 2012, 'Kétfahegyi-tető' 2006, 'Ivány-hát' 2007, 'Pórag-hát' 2017, 'Láz-tető', 'Barbacs-erdő' 2008, 'Szapu-völgy' 2009. Keszthely: 'Bottyán-hát', 'Kö-hát' 2016, 'Nagy-Messzelátó’ 2011. Gyenesdiás: 'Pilikán' 1997, 'Nagy-Messzelátó' 1997, 'Pórag-hát' 1996, 'Pajta-völgy' 1997, 'Öreg-Szék-tető’ 1997, 'Nyilas-erdő' 2000, ‘Tüskés-lap' 1992, 'Kesello’’ 1997, 'Meszes-hegy' 2015. Vonyarcvashegy: 'Vonyarci-fenyves' 2019, 'Csalános-völgy' 2012, 'Vonyarci-cser' 2019, 'Malacos-tető' 2019, 'Nyulas' 2019. Balatongyörök: 'Büdöskúti-arborétum' 1998, 'Vashegyierdő' 2019, 'Gotthár-sík' 2019, 'Szénégető-nyiladék' 2008, 'Garga-hegy’ 2019, 'Paphegyi-ugrató’ 2019, 'Apró-hegyek' 2019, 'Virágos-hegy’ 2019.

KEF: 9066.3, 9067.1, 9067.3, 9067.4, 9069.3, 9069.4, 9165.4, 9165.1, 9165.2, 9165.3, 9166.1, 9166.3, 9166.4, 9167.1, 9167.2, 9167.3, 9167.4, 9168.1, 9168.3, $9169.1,9169.2,9169.3,9169.4,9170.3,9264.1,9265.2,9265.3,9265.4,9266.1$, $9266.2,9266.3,9266.4,9267.1,9267.2,9267.3,9268.1,9269.2,9365.2,9365.4$, 9366.2, 9366.3, 9366.4, 9367.3, 9368.1, 9464.2, 9465.1, 9465.2, 9465.4, 9466.1, 9466.2, 9466.3, 9466.4, 9467.1, 9467.3, 9468.1, 9468.2, 9468.3, 9566.1, 9566.2, $9567.2,9567.3,9567.4,9568.2,9568.3,9568.4,9667.2,9668.2,9668.3$. 


\section{Cephalanthera damasonium (Mill.) Druce}

Habitat: beech forests, (sessile) oak-hornbeam forests, pine woods, pine plantations, chestnut plantations.

H: Rédics: 'Nagy-Tenke’ 2005. G: Zalaegerszeg: 'Alsóerdő' 2006. Bak: 'Botosierdő' 2008, 'Nénai-erdő' 2014. Kustánszeg-Parasza: 'Balhás' 2011. Szentpéterfölde: 'Szálas-erdő’ 2017, 'Kis-Berkes' 2003. ELd: Kemendollár: 'Körtefai-dűlo’’. Nemesapáti: 'Kanta-hegy’. Alsónemesapáti: ‘Álófaludi-erdő', 'Pad-oldal-dűlö'. Petőhenye: 'Ördög-domb' 2009, 'Avas-hegy' 1996, 'Csillag-hegy' 2005, 'Alsó-erdő' 2011. Zalaegerszeg-Csácsbozsok: ‘Csácsi-arborétum’ 2000, 'Csácsi-erdő' 2010. Zeg-Botfa: 'Karácsony-hegy’ 2010, 'Bokáncs’ 2010. Alsónemesapáti: 'Átófaludierdő', 'Padalja' 2010. Nemessándorháza: 'Szoboszlói-hegy’ 2005. Csatár: 'Macskadelelő' 2016, 'Remete', 'Csatári-hegy' 2015. Nagykapornak: 'Körtvélyesi-erdő' 2016, 'Kalamászos-erdő’ 2011. Pölöske: 'Öreg-hegy' 2015, 'Benevölgyi-dűlő' 2006, 'Barnaki-bükk-tető' 2011. Zalaszentmihály: 'Koldus-hegy', 'Horvát-hegy' 2012. Bucsuta: 'Bán-kürtős' 2015, 'Fehérbükki-erdő' 2014, 'Büki-erdő' 2012, 'Alsó-erdő' 2007. Oltárc: 'Vár-domb' 2012. Valkonya: 'Franci-köz' 2005. Eszteregnye-Obornak: 'Várbükki-erdő' 2010, 'Szorosas', 'Gyurkáncsi-erdő’ 2015, in spruce forest near the forester's lodge 2010. Bázakerettye: 'Kozári-dülo’’ 2011, in the sports court 2015. Lasztonya: 'Erdőháti-erdo’' 2016. Tormafölde: 'Centrálé' 1995, ‘Vétyemi-erdo’’ 1999. Páka: ‘Banai-erdő' 2013. Maróc: ‘Maróci-hegy’ 2004, 'Hosszú-hegyháti-dűlő', 'Temetői-oldal' 2010. Szentmargitfalva: 'Rózsa-hegy' 1996. Muraszemenye: 'Kopasz-domb’ 1997. Zah: Zalaszentgrót-Aranyod: 'Felső-Aranyod' 1995. Pakod: 'Borbás-hegy' 1997. Zalaistvánd: 'Istvándi-erdő' 2014, 'Pácz-tető' 2017. Bezeréd: 'Felső-erdő' 2012, 'Bezerédi-hegy' 2011. Kallósd: 'Kúthegy' 1994. Padár: 'Felső-erdo’’ 2011. Nagykapornak: 'Bánfai-erdő' 2012, 'Remetekert' 2005. Zalacsány: 'Csányi-erdő' 2010. Dióskál: 'Arany-kút' 2010, 'Pogányvár' 2006. Esztergályhorváti: 'Patakon-aluli-dűlő' 2005. Újudvar: 'Korágó' 2012. Nagybakónak: 'Pakarics-hegy' 2010. Khg: Rezi: ‘Almás-domb’ 2012, 'Kozma-tetö' 2010, 'Keserü-torony' 2011, 'Fagyoskereszt' 2012, 'Meleg-hegy' 2010, 'Rezi-vár' 2012, 'Bányafö-tető' 2015. Cserszegtomaj: 'Gyötrös' 2012. Vállus: 'Messzi-domb' 2017, 'Vadvíz-árok' 2009, 'Iván-hát' 2011, 'Büdöskúti-erdő’ 2006, 'Büdöskúti-erdészház' 2015, 'Kétfahegyi-tető' 2012, 'Kis-Láz-völgy', ‘Szent-Miklós-forrás’ 2009, 'Szapu-völgy' 2011, ‘Abrincsos-völgy’ 2014. Keszthely: ‘Tömlöchegy' 2005, 'Szár-hegy', 'Pilikáni-út' 2005, 'Négyszögü-hegy', 'Nagy-Messzelátó' 2011. Gyenesdiás: 'Lakatos-hegy' 2006, 'Kesellő’ 1997, 'Pilikán’ 2005, ‘Tüskéslap' 1997, 'Öreg-Szék-tető' 1997, 'Ló-hegy' 2006. Balatongyörök: 'Pad-kői-erdo’', 'Büdöskúti-arborétum' 2011, 'Boncsos-tető', 'Keserü-berek' 2016. Lesencefalu: ‘Gesztenyés’ 1991, 'Kőris-völgy’, 'Nyilvány’ 2016. 
KEF: 9067.4, 9068.1, 9068.3, 9166.4, 9167.1, 9167.2, 9167.3, 9167.4, 9168.1, $9168.3,9169.1,9169.2,9169.3,9169.4,9170.3,9266.1,9266.2,9266.4,9267.1$, $9267.3,9268.1,9269.2,9366.3,9367.3,9368.1,9368.2,9465.1,9465.2,9465.4$, $9466.1,9466.2,9466.3,9466.4,9467.1,9467.3,9468.1,9468.2,9468.3,9565.2$, 9566.1.

Cephalanthera $\times$ schulzei E. G. Camus (C. longifolia $\times$ C. damasonium)

Habitat: (sessile) oak-hornbeam forests, scrubs.

ELd: Maróc: 'Maróci-hegy' 2010. Khg:Vállus: 'Kis-Láz-völgy' 2014.

KEF: 9169.4, 9466.1.

Neottia ovata (L.) Bluff. \& Fingerh.

Habitat: (sessile) oak-hornbeam forests, fens, orchards, chestnut plantations, scrub.

FKh: Bagod-Szentpál: 'Kút-völgy’ 2003. Nagykutas: 'Szőlőhegy’ 1991. Egervár: ‘Csillag-hegy’ 2011, 'Pince-domb’ 2005, 'Kápolnai-domb’ 2013, 'Kövecses-alja' 1993. Lakhegy: 'Kullancs-hegy' 1991, 'Kis-hegy' 2000. Gösfa: 'Felső-hegy' 2004, 'Vitárgya' 1991, 'Bük' 2005. Vasboldogasszony: 'Kakas-szőlö' 2005, 'Ambói-hegy' 2007. H: Magyarföld: 'Berki-hegy’ 2008. G: Zalalövő: 'Pacsa-hegy' 1995. HottóZalaszentmihályfa: 'Pergyászlói-hegy' 1991. Zalaegerszeg: 'Alsóerdő' 2011, 'Gálafej’ 2008, 'Jánka-hegy' 2011. Zalaegerszeg-Zalabesenyő: ‘Téglaszíni-dűlő' 2008. Gombosszeg: orchards 2016. Milejszeg: 'Lóka-hegy’ 2007. Nagylengyel: ‘Új-hegy' 2010. Gellénháza: 'Budai-hegy' 2011. Lenti: 'Csalános' 1996. Nova: 'Felső-hegy' 2009. Sárhida: 'Csöpögő’ 2009. ELd: Zalaistvánd: orchards 1994, 'Barkus-hegy' 2011. Kemendollár-Kemend: 'Alhegyi-dülő' 1991, 'Kemendi-hegy' 2004, 'Csertóidülő' 2009. Petőhenye: 'Malom-domb' 1996, 'Ördög-domb’ 1991, 'Kápolna-hegy' 1996, 'Torma-hegy' 1992. Nemesapáti: 'Compó-rét' 2017, 'Kis-Újhegy’ 2008, 'Kanta-hegy' 2011. Alsónemesapáti: 'Bük-sürü' 1995, ‘Csönkölei-hegy' 1991, 'Belső-hegy' 1994, 'Nagy-Újhegy' 2015. Zalaegerszeg-Csácsbozsok: 'Csácsi-hegy' 2005, 'Mándi-domb’ 2005. Zalaegerszeg-Botfa: ‘Újhegy' 2006. Kisbucsa: ‘Szarkahegy' 2015, 'Hosszú-hegy' 2011, 'Nagy-tábla-dűlő' 1994. Nemeshetés: 'Gesztenyés' 2015. Nagykapornak: 'Váras-hegy’ 2015. Csatár: 'Csatári-hegy’ 2011, 'Kincsemhegy’ 2000. Pölöske: ‘Öröm-hegy’ 2013, ‘Öreg-hegy’ 2015, ‘Kis-hegyi erdő’ 1995. Zalaszentmihály: 'Koldus-hegy' 2005. Szepetnek: along 'Kis-réti-patak' 2008 (H. T.). Páka-Dömefölde: 'Lakosa-hegy' 2013, 'Dömeföldi-hegy' 2002, 'Kányavári-hegy' 2013. Maróc: 'Maróci-hegy' 2013. Lispeszentadorján: 'Adorjánihegy' 2014. Bázakerettye-Kerettye: orchard of the social welfare institute 2011 (B. Á.), at the margin of 'Kozári-erdo’’ 2011. Muraszemenye: ‘Csányi-hegy’ 2010. Börzönce: 'Tuboly-szer' 2011. Prv: Sormás-Nagykanizsa: 'Gördövény' 1995, 
Nagykanizsa: 'Osztott-rétek' 2014. Zah: Zalabér: 'Kápolnai-oldal' 2008. Zalaszentgrót-Aranyod: 'Csernak' 2013, 'Felsö-Aranyod' 2005. Zalaszentgrót-Csáford: 'Som-tető' 2008, 'Bogos-domb' 2005, 'Koppány-hegy' 2001. Zalaistvánd: 'Pácz-tető'. Bezeréd: 'Bezerédi-hegy' 2008. Gyürűs: 'Öreg-hegy' 2011. Kallósd: ‘Öreg-hegy' 2011. Padár: 'Zsidó-föld' 2013. Nemesrádó: 'Rádi-hegy’ 2008. Dióskál: 'Öreg-hegy' 2018, 'Szegfalusi-hegy' 2009. Kerecseny: 'Bagácsa' 2008, 'Fehérhegy' 2007. Újudvar: 'Csibit' 1993. Zalamerenye: 'Öreg-hegy' 2005. Surd: 'Szakály-hegy' 2012. AZv: Zalaszentgrót: 'Dombos-rét' 2013. Zvh: Türje: 'Kopaszhegy' 2015. Zalaszentgrót: 'Huszonya' 2006, 'Bujtor-domb' 2010, 'Pityer-domb' 1995. Sénye: 'Új-hegy' 1996. Zalaköveskút: 'Gesztenye-hegy' 2011. Karmacs: 'Keresztúr-puszta' 2011, 'Vizes-rét' 1994. Hévíz: in the park of the spa 2002. Tcs: Nagygörbő: 'Szőlőhegy' 1994. Sümegcsehi: 'Derék-hegy' 2012. Lesenceistvánd: 'Csengö' 2015. Khg: Rezi: 'Almás-domb' 2005. Vállus: 'Kétfahegyi-tető' 2006. Gyenesdiás: 'Kis-Messzelátó' 2017. Keszthely: 'Szoroshadi-út' 1994, 'Festeticskilátó' 2005. Lesencefalu: 'Gesztenyés' 1991. Lesenceistvánd: 'Csengő' 2015. Kbm: Balatonszentgyörgy: 'Szentgyörgyi-legelö' 2009.

KEF: 9066.3, 9066.4, 9067.1, 9067.2, 9067.3, 9067.4, 9068.1, 9068.2, 9068.3, 9068.4, 9069.3, 9165.3, 9166.3, 9166.4, 9167.1, 9167.2, 9167.3, 9167.4, 9168.1, 9168.2, 9168.3, 9168.4, 9169.1, 9169.3, 9169.4, 9170.3, 9264.1, 9265.4, 9266.2, 9266.3, 9267.1, 9267.2, 9268.1, 9269.1, 9269.2, 9269.4, 9365.4, 9368.1, 9368.3, 9369.2, 9465.2, 9466.1, 9466.3, 9467.1, 9467.4, 9468.1, 9468.2, 9565.2, 9566.1, 9567.2, 9567.3, 9667.4.

Neottia nidus-avis (L.) Rich.

Habitat: (sessile) oak-hornbeam forests, beech forests, pine-oak forest, pine plantations.

FKh: Vaspör: 'Aszalósi-dűlő' 2008, 'Pap-erdő' 2008. Zalaszentgyörgy: 'Saisdülő' 2005, 'Úrbéri-erdő’ 2007, 'Pap-erdő' 1990. Gösfa: 'Bótus' 1995, 'Bükkös' 1995. Vasboldogasszony: 'Kövecses' 1993, 'Csöngeti-erdo’' 2000. Egervár: 'Kövecs' 2000, 'Vörös-alja' 1997. Zalaszentlörinc: 'Tölgyes' 1991. Zalaszentiván: 'Vörös-erdö' 2007. H: Csöde: 'Kelü' 2011, 'Farkas-lik' 2011, 'Németi-parag' 2008, 'Szelencés' 2006. Magyarföld: 'Dobráji-erdő’ 2008, 'Csipán-bük' 2008, 'Bükkös-erdő' 2008. Szentgyörgyvölgy: 'Haraszti-erdő' 1998. Rédics-Lendvakecskés: 'Kelekút' 2005, 'Sándor-gesztenyés' 2005. Lendvadedes: 'Kövecse' 2008. Lenti: 'Előhegy' 2010, 'Zajdai-erdő' 1995. Lenti-Máhomfa: 'Török-erdö’ 2010. G: Zalalövő: 'Kecskéshát' 2010, 'Pacsa-erdő' 2009, 'Bankó-part' 2018, 'Borostyánvölgyi-forrás' 2018, 'Szarka-szél' 2008, 'Laki-erdő' 2015, 'Méhesirsai-erdő' 2009, 'Nyerges' 2011, 'Macskás' 2008, 'Csaló-kereszt' 2015. Keménfa: 'Kerek-domb' 2012. 'Tompa-erdő' 2012. Salomvár: 'Gerencsér-lik' 2016, 'Salomvári-erdő' 2016, 'Akasztott-aszony- 
dombja' 2010. Kávás: 'Zalósznoki-dűlő' 2018, 'Zsimbahegy-alja' 1999. Böde: 'Boros-erdő' 2010, 'Öreg-hegy' 2010, 'Alsó-erdő' 2011. Babosdöbréte: 'Döbréteierdő’ 2000. Zalaegerszeg: ‘Alsó-erdő' 1995, 'Bagodi-erdő' 1995. Kerkakutas: 'Nyíresd' 2011, 'Magyarósd' 2011. Kozmadombja: 'Ispányi-sűrü' 2006, 'Jáhomi-erdő' 2006. Pusztaapáti: ‘Apáti-erdő' 2016, 'Apáti-puszta’ 1992. Kálócfa: ‘Haraszt' 2009. Pórszombat: 'Zenfa-erdő' 2000. Kerkabarabás: 'Lakosiárok-mellék' 2007, 'Cserhegyi-erdő' 2007. Lenti-Lentiszombathely: 'Malonyai-erdő' 2012, 'Csalános' 1990, ‘Zajdai-erdő'. Hernyék: 'Szalmahídi-erdő' 2008, ‘Gyertyános' 2008. Nova: 'Lőrincfai-mellék’ 2016, 'Úrbéri-erdő' 2016, 'Hosszú-bránás’ 2016. Szilvágy: ‘Orbán-lap' 2009, 'Tekeres' 2008, 'Kerek-fenyves' 2011, 'Alsó-erdő' 2016. 'Kis-Zsibos' 2018, 'Mutatófa' 2009. Kustánszeg: 'Kertesi-dűlő' 2011, 'Kisnemes' 2011. Németfalu: 'Péter-erdő' 2016. Milejszeg: 'Feneketlen-kút' 2017, 'Csarit' 2011, 'Kis-hegy' 2011, 'Gesztenyés' 2012. Csonkahegyhát: 'Füzér-feletti' 2009, 'Sas-irtása' 2009. Becsvölgye-Kislengyel: 'Horvát-ház' 2010. Becsvölgye-Pajzsszeg: 'Buhás' 2011, 'Kis-bükkös' 2011. Becsvölgye-Simonszer: 'Darab-erdő' 1997. Nagylengyel: 'Csentericsfa' 2004. Lickóvadamos: 'Csöpögő' 2013. Petrikeresztúr: 'Bükk-oldal' 2013. Zalatárnok: 'Nénai-erdo”' 2008. Bak: 'Új-Avas' 2005, 'Botosi-erdő' 2008, 'Felső-erdő', 'Nénai-erdő' 2006. Sárhida: ‘Közös-erdő’ 2003. Ortaháza: 'Kocsmahegyi-erdö' 1996. Iklódbördőce: 'Marton-völgy-oldal' 2016, 'Csokmányi-erdö' 2016. Pördefölde: 'Pördeföldi-erdő' 2011. Szentpéterfölde: 'Szálas-erdő' 2011, 'Kis-berek' 2017, 'Gesztenyési-hegyhát' 2017. Bánokszentgyörgy: 'Keresztesierdő’ 2008, 'Bunya' 2008. Várfölde: ‘Nyírlakosai-erdo’’ 2014, 'Községi-erdő’ 2014. ELd: Kemendollár: 'Bükki-erdő' 2010, 'Körtefa-dűlő' 2010. Vöckönd: 'Bükk-alja' 2010. Zalaszentiván: 'Magasmán' 1993. Petőhenye: 'Magasmán', 'Vaskó-hegy' 2008, 'Cigány-hegy' 1992, 'Tót-hegy' 1991, 'Cser-hegy’ 1991, 'Alsó-erdo’' 2011. Nemesapáti: 'Hosszú-bükk' 1995, ‘Bucsai-erdő' 1995. Alsónemesapáti: 'Átófaludierdő' 2010, 'Pad-alja' 2010, 'Bucsai-erdő' 1995. Zalaegerszeg-Csácsbozsok: 'Csácsi-arborétum' 2013, ‘Csácsi-erdo’’ 2005. Zalaegerszeg-Botfa: ‘Csapás’ 2010, ‘Karácsony-hegy' 2010, 'Bokáncs' 2010, 'Rózsás' 2011. Nemeshetés: 'Gesztenyés' 2015. Nagykapornak: ‘Körtvélyesi-erdő' 2016, 'Kalamászos-erdő' 2012. Misefa: 'Szálas' 2015. Csatár: 'Csatári-hegy' 2011, 'Pusztika' 2009. Pölöske: 'Eduárd-nyiladék' 2016, 'Béla-tanya-erdő' 2012, 'Hálási-lap' 2012, 'Féligbaki-erdő' 2015, 'Nagy-hányási-erdő’ 2018, 'Pölöskei-erdő' 2009, 'Kovács-hegy' 2016, 'Bükk-tető' 2008. Nemessándorháza: 'Szoboszlói-hegy' 2008. Söjtör: 'Sántaszer' 2011, 'Bükkalja' 2015, 'Felső-erdő' 2008, 'Csákány-völgy' 2008, 'Farkas-völgy' 2008. Pusztamagyaród: 'Alsó-erdő' 2014. Hahót: 'Osztott-erdő' 2010, 'Tompa-hegy' 2010. Bucsuta: 'Bán-kürtős' 2015, 'Fehérbükki-erdő' 2012, 'Szekrényesi-oldal' 2008, 'Pörkölt-csádé' 2009. Oltárc: 'Kövecses-hegyhát' 2016, 'Kútfej-erdő’ 2009, 'Márkierdő’ 2017, ‘Vár-domb’ 2012, ‘Horváti-erdő’ 2016. Valkonya: ‘Úrbéresi-erdő’ 1996, 'Hercseg-erdő' 1996. Eszteregnye-Obornak: 'Gyurkáncsi-erdő' 2010, 'Kisbükki- 
oldal' 2010, 'Zsindelyes' 2012, 'Várbükki-erdő' 2010, 'Szorosos' 2012. Becsehely: 'Barkóczás' 2011. Letenye: 'Vörcsöki-erdő' 1998, 'Billegi-erdő' 1998. Kistolmács: 'Kozár' 2010. Páka-Dömefölde: 'Fejérlakosa-erdő’ 2017. Iklódbördőce: 'Martonvölgyi-oldal' 2010, 'Csokmai-erdő' 2005. Szécsisziget: 'Martonvölgyi-oldal' 2010, 'Iszkonaki-erdő' 1998. Tormafölde: 'Vétyemi-erdő' 1992. Dobri: 'Hegyvámos' 2017. Csörnyeföld: 'Vörcsöki-erdő' 2017, 'Basai-erdő' 2017. Muraszemenye: 'Alsó-erdo’’ 2010, 'Közbirtokossági-erdo’' 2010. Szentmatgitfalva: 'Öreg-hegy' 1996. Lasztonya: 'Erdőháti-erdő' 2016. Lispeszentadorján: 'Lispei-erdő' 2009, 'Keresztfai-erdő' 2016. Bázakerettye: park of the swimming pool 2011. Zajk: 'Északi-erdo’' 2008. Bánokszentgyörgy: 'Haraszti-erdő' 1998, 'Keresztesi-erdő' 2005, 'Bunya' 2005. Zah: Zalabér: 'Kányakúti-erdő'. Zalaistvánd: 'Istvándi-erdő' 2007, 'Páctetö' 2017. Bezeréd: 'Felső-erdö' 1998. Padár: 'Felső-erdö' 2011, 'Hamuházi-tábla' 2011. Zalaszentgrót-Csáford: 'Buggos' 2010. Ligetfalva: 'Cseri-erdő' 2006. Nagykapornak: 'Alsó-erdo’' 2014, 'Bánfai-erdo”' 2012, 'Remetekert' 2004. Zalacsány: 'Körtvélyesi-erdo’' 2009. Zalaapáti: 'Felső-erdő' 2006. Zalamerenye: 'Kö-völgy' 2005, 'Kanicza-erdő' 2000. Zalakaros: 'Kanicza-erdo’' 2017. Újudvar: 'Korágó' 2012, 'Csibit' 1993. Nagybakónak: 'Kőszurdok' 2009. Nagykanizsa: 'Alsó-erdő' 2019. Nagykanizsa-Miklósfa: 'Mórichelyi-bükk' 2016. Liszó: 'Lesházi-nyiladék' 2016. Miháld: 'Muszinadola' 2009. Zvh: Sénye: 'Nagyhegyi-sürü' 1996. Tcs: Zalaszántó: 'Kovácsi-hegy' 2011, 'Tátika' 2016. Bazsi: 'Szebike' 2011. Várvölgy: 'Hosszú-hegy' 1995. Lesenceistvánd: 'Kö-orra' 1996. Khg: Rezi: 'Almás-domb' 2011, 'Bottyán-hát' 2011, 'Hosszú-völgy' 2012, 'Púpos-hegy' 2008, 'Szent-kút' 2016, 'Meleg-hegy' 2007, 'Rezi-vár' 2005, 'Bányafö-tető' 2016, 'Pajta-völgy' 2011, 'Pap-út' 2011, 'Pörkölt-hegyek' 1995, 'Láz-tetö', 'Kis-Cser-völgy' 2010, 'Hidegvölgy' 2010, 'Keserütorony-hegyek' 2009, 'Fagyoskereszt' 2009. Vállus: 'Pórag-hát' 2017, 'Ivány-hát' 2017, 'Iván-hát' 2007, 'Messzi-domb' 2008, 'Borzas-lapos', 'SzentMiklós-forrás', 'Büdös-kúti-erdö' 2006, 'Büdös-kúti-erdészház' 2001, 'Vadvízárok' 2010, 'Kétfahegyi-tető' 2012, 'Rózsa-mező' 2011, 'Képestói-putri' 2017, 'Égetett-vágás', 'Ivány-hát', 'Sáros-tói út'. Keszthely: 'Tömlöc-hegy' 2003, 'Pilikánierdő' 2009, 'Négyszögü-hegy' 2006, 'Kis-Messzelátó' 2012, 'Nagy-Messzelátó' 2009. Gyenesdiás: 'Pilikán' 1997, 'Meleg-hegy' 1993, 'Varsás-hegy' 1995, 'Nyilaserdő' 2008, 'Tüskéslap' 1995, 'Kesello’' 2008, 'Csider-völgy' 1998, 'Ló-hegy' 2006, 'Szík-tető' 1995, 'Öreg-Szék-tető' 1999. Vonyarcvashegy: 'Vonyarci-fenyves' 1991, 'Vas-hegy' 2019, 'Vonyarci-cser' 2019, 'Hosszú-völgy' 2019, 'Malacos-tető' 2019, 'Csalános-völgy' 2019. Balatongyörök: 'Csereze-hegy’ 2019, 'Vashegyi-erdő' 2019, 'Kerék-hegy' 2005, 'Padkői-erdő' 2006, 'Boncsos-tető' 2014, 'Büdöskút' 1994, 'Garga-hegy' 2008, 'Keserü-berek' 2014. Balatonederics: 'Edericsi-plató’ 2008. Lesencefalu: 'Gesztenyés' 1991.

KEF: 9066.3, 9066.4, 9067.1, 9067.3, 9067.4, 9068.3, 9165.4, 9165.1, 9165.3, 9166.1, 9166.3, 9166.4, 9167.1, 9167.2, 9167.3, 9167.4, 9168.1, 9168.2, 9168.3, 
$9169.1,9169.2,9169.3,9169.4,9170.3,9264.1,9264.3,9265.1,9265.2,9265.3$, 9265.4, 9266.2, 9266.4, 9267.1, 9267.3, 9268.1, 9268.4, 9269.2, 9270.1, 9365.1, $9365.2,9365.3,9365.4,9366.3,9366.4,9367.1,9367.3,9464.2,9465.1,9465.2$, 9465.4, 9466.1, 9466.2, 9466.3, 9466.4, 9467.1, 9467.3, 9467.4, 9468.1, 9468.2, 9468.3, 9565.2, 9566.1, 9566.2, 9567.1, 9567.2, 9567.3, 9568.1, 9568.2, 9667.2, 9668.3.

\section{Epipactis palustris (L.) Crantz}

Habitat: tall-sedge vegetation, mesotrophic wet meadows, fens, fallows, steppes.

FKh: Egervár: 'Kápolna-domb' 2013. FZv: Zalaegerszeg-Pózva: 'Pózvai-tavak' 1990. G: Bocfölde: 'Bogárdi-rétek’ 1991, meadows along the railroad 1991 (†). Sárhida: 'Válicka' 1991, ‘Csöpögő' 1991. Bak: ‘Gula-berek' 1993.ELd:Zalaistvánd: 'Barkus-hegy' 2009. Zalaegerszeg-Csácsbozsok: 'Bozsoki-domb' 1993, verge of road Nr $761995(†)$. Alsónemesapáti: 'Bük-sürü’ 2004. Nemessándorháza: 'Kühegy’ 2006.Bucsuta: 'Peteházi-láprét' 2007. Sormás-Nagykanizsa: ‘Gördövény’ 1991. Nagykanizsa: 'Császár-rét' 2001. Muraszemenye-Aligvár: 'Csányi-hegy' 2010. Bánokszentgyörgy: 'Külső-hegy’ 2014. Prv: Pölöske: 'Éva-sziget' 1996, peat mine 2004. Fűzvölgy: 'Berki-rétek' 2004. Nagykanizsa-Miklósfa: 'Mórichelyihalastavak' 1995. Zah: Zalaszentgrót-Aranyod: 'Csernak' 2013. ZalaszentgrótCsáford: 'Aszó-tető' 2013. Zalaszentgrót-Zalakoppány: 'Koppány-hegy' 2010, 'Rátka-hegy' 1995. Kallósd: 'Öreg-hegy' 2014. Szentpéterúr: 'Nemesszer' 1991. Kerecseny: 'Fehér-hegy' 2013. AZv: Batyk: 'Síki-rét', along 'Zala' 1992. Zalaszentgrót-Tüskeszentpéter: 'Dombos-rét' 1992. Zvh: Zalaszentgrót: 'Pityer-domb' 2010. Zalaszentlászló: ‘Öreg-hegy' 1996. Zalaköveskút: 'Kis-hegy' 2008. Tcs: Várvölgy: 'Bándi-mező' 1990. Khg/Tm:Lesenceistvánd: 'Csuhus-rét' 1990.Lesencetomaj: 'Serény’, 'Homoki' 1990. Tapolca: 'Viszló-mente’ 1990. Kbm: Keszthely-Fenékpuszta: 'Balaton-part' 1990. NybS: Zalakaros: 'Gástya', 'Bodoni-rét', along 'Banyavölgyi-patak' 2002. Galambok: 'Vadszürü-dűlő' 2004.

KEF: 9067.1, 9068.1, 9068.3, 9068.4, 9167.2, 9167.3, 9168.1, 9168.2, 9169.2, $9170.1,9170.2,9267.1,9267.2,9267.3,9267.4,9268.1,9269.3,9368.3,9466.2$, 9467.4, 9468.2, 9565.2, 9567.2, 9567.4.

\section{Epipactis microphylla (Ehrh.) Sw.}

Habitat: (sessile) oak-hornbeam forests, beech forests, pine-oak forest.

G: Bak: 'Botosi-erdő’ 2012. ELd: Petőhenye: ‘Cigány-hegy' 1996, 'Avas-hegy' 1996, 'Alsó-erdő' 2012. Zalaegerszeg-Csácsbozsok: 'Csácsi-arborétum' 2000, 'Csácsi-erdő’ 2005. Zalaegerszeg-Botfa: 'Bokáncs' 2009. Alsónemesapáti: 'Padalja' 2010. Bucsuta: 'Fehérbükki-erdő' 2015. Tormafölde: ‘Ösbükkös', 'Vétyemi- 
erdő' 1995, Bánokszentgyörgy: 'Vár-domb' 2012. Eszteregnye-Obornak: 'Várbükki-erdő', 'Szorosos' 2012. Bázakerettye: park of the spa 2015. Maróc: 'Temetői-oldal' 2010. Zah: Zalaistvánd: 'Pácz-tető' 2017, 'Istvándi-erdő' 2014. Padár: 'Felső-erdő' 2012. Nagykapornak: 'Bánfai-erdő', 'Remetekert' 2012. Zalacsány: 'Körtvélyesi-erdő' 2010. Újudvar: 'Korágó' 2012. Khg: Rezi: 'Pajta-völgy' 2016, 'Fagyoskereszt' 1993, 'Szentmiklósi-völgy' 2014. Keszthely: 'Négyszögü-hegy' 2012. Gyenesdiás: 'Kesello’’ 2009. Balatongyörök: 'Büdöskúti-arborétum’ 2010, 'Kígyós-völgy' 2010, 'Boncsos-tetö’ 2014, 'Kis-Püspökház-völgy' 2012, 'Keserüberek' 2014. Vállus: 'Láz-tető', 'Iván-tető’ 2017, 'Abrincsos-völgy' 2008, 'Büdöskúti-erdő' 2012, 'Vékony-cser' 2016, 'Köves-tető' 2012, 'Szent Miklós-forrás', 'Szapu-völgy'2009. Mh: Hollád: 'Vadaskert-erdő’ 2016.

KEF: 9068.3, 9167.1, 9167.2, 9167.3, 9167.4, 9168.1, 9168.3, 9169.2, 9169.4, $9170.3,9266.2,9267.1,9268.1,9465.2,9466.3,9467.1,9467.3,9468.3$

\section{Epipactis atrorubens (Hoffm.) Besser}

Habitat: scrub forests, beech forests.

ELd: Zalaegerszeg-Csácsbozsok: Csácsi-erdő 2010, Murarátka: 'Rátkaierdő' 1990 (H. Zs.). Khg: Cserszegtomaj: ‘Okkerbánya' 2012. Keszthely: 'Négyszögü-hegy' 2004, 'Festetics-kilátó’ 2005. Gyenesdiás: 'Nagy-Messzelátó' 1997, 'Szík-tető' 1997, 'Pórag-hát' 2009, 'Pilikán' 1997, 'Nyilas-erdő', ‘Tüskéslap', 'Kesellö' 1993.

KEF: 9167.3, 9169.4, 9269.2, 9465.2.

\section{Epipactis helleborine (L.) Crantz}

Habitat: scrub forests, beech forests, hornbeam forests, pine-oak forest, pine plantations, poplar plantations.

FKh: Nagykutas: 'Szőlőhegy' 2009. FZv: Zalaegerszeg-Csácsbozsok: 'Parkerdö' 1991. H: Csöde: 'Farkas-lik' 2011. Kerkafalva: 'Körtvélyesi-erdo”’ 2009, along 'Szatta-patak' 2008, 'Barátos' 2016, 'Nyíresd' 2014. Lenti: 'Elő-hegy' 2005. Gosztola: 'Héjasházi-erdő' 2005. Rédics-Lendvakecskés: 'Kelekút', 'Sándor-gesztenyés' 2005. Tornyiszentmiklós: 'Koldustemető' 2008. G: Zalalövő: 'Bankó-part' 2009, 'Nyerges' 2011, 'Laki-erdő' 2015, 'Irsai-erdő' 2009, 'Gizella-major' 2012. Salomvár: 'Gerencsér-lik' 2016, 'Salomvári-erdő’ 2016. Böde: 'Körtvélyes’ 2018, 'Cseresnyés' 2000, 'Boros-erdő’ 2010. Németfalu: 'Bábos-sűrü. Csonkahegyhát: 'Dal-hegy' 2016. Milejszeg: 'Gesztenyés' 2010. Kerkakutas: 'Magyarósd' 2006, 'Nyíresd' 2014. Pusztaapáti: 'Szőlőföldi-oldal' 1992, 'Szalonnás-árok', 'Szilvágyszél' 2008. Kálócfa: 'Mihom' 2009. Pórszombat: 'Zenfa-erdő' 2000, 'Szilvágyi-szél' 2008. Szilvágy: 'Határ-hegy' 1990, 'Alsó-erdő' 2015, 'Kerek-fenyves' 2011, 'Nagyberek-víz’ 2016, 'Felső-erdö’ 1992, 'Mutatófa' 2009. 'Kis-Zsibos' 2016. Becsvölgye- 
Simonszer: 'Darab-erdő’ 2010. Becsvölgye: 'Salomfa' 2016. Milejszeg: ‘Gesztenyés' 2010. Gombosszeg: 'spruce plantation' 2016. Zalaegerszeg: 'Aranyos-lapi-forrás' 2004. Bak: 'Botosi-erdő' 2008, 'Nénai-erdo’’ 2006. Petrikeresztúr: 'Bükk-oldal'. Nova: 'Lőrincfa-mellék' 2006, 'Olga-major' 2009, 'Úrbéri-erdő' 2010. Pördefölde: 'Pördeföldi-erdő' 2017. Szentpéterfölde: 'Kis-berkes' 2003. Kerkabarabás: 'Lakosiárok-mellék' 2007. Lenti-Mumor: 'Csalános' 2016, 'Malonyai-erdő' 2011. Hernyék: 'Szalamhídi-erdő' 2016, 'Zajdai-erdő' 2008, ‘Gyetyános' 2008, 'Bördöceipatak' 2008, 'Gálosi-nyiladék' 2008. Gellénháza: 'Pipa-hegy’ 2013. ELd: Petőhenye: 'Csillag-hegy' 1996, 'Cigány-hegy' 2010. Zalaegerszeg: 'Csácsi-erdo’' 2004. Zalaegerszeg-Botfa: 'Karácsony-hegy' 2014, 'Bokáncs' 2002. Pölöske: 'Kovácshegy' 2009. Bucsuta: 'Bán-kürtős' 2015, 'Fehérbükki-erdő' 2014, 'Büki-erdő', 'Szekrényesi-oldal' 2009, 'Pörkölt-csádé' 2012, 'Alsó-erdő' 2009. Oltárc: 'Kútfejerdő' 2009. Eszteregnye-Obornak: 'Gyurkáncsi-erdo’' 'Várbükki-erdő', 'Szorosos' 2010, forester's lodge 2010. Tormafölde: 'Vétyemi-erdő' 2006. Prv: Nagykanizsa: 'Gördövény’, 'Hidegkúti-erdő' 2008 (H. T.). Szepetnek: ‘Csicsa-kunyhó', 'Cerinaerdő', 'Róka-domb' 2008 (H. T.). Zah: Zalaistvánd: 'Pácz-tető' 2017. Padár: 'Felsőerdő' 2011. Nagykapornak: 'Bánfai-erdo’’ 2017, 'Remetekert' 2012. Zalacsány: 'Körtvélyesi-erdő' 2012. Újudvar: 'Csibit' 1993. Nagybakónak: ‘Török-föld' 2012. Zalamerenye: 'Kanicza-erdo’’ 2004. Miháld: 'Muszinadola' 2009 (F. S.). Nagykanizsa-Nagyfakos: 'Gesztenyés' 2009 (F. S.). Tcs: Zalaszántó: 'Tátika' 2016. Khg: Rezi: 'Koma-tetö' 2010, 'Kis-Cser-völgy' 2009, along 'Várvölgyi' street 2004, 'Fagyoskereszt' 1992, 'Keserütorony-hegyek' 2011. Keszthely: 'Négyszögletűhegy’ 2006, 'Nagy-Messzelátó' 2006, 'Festetics-kilátó' 2005, 'Kübánya' 1992. Gyenesdiás: 'Pórag-hát' 1995, 'Tüskéslap', 'Kesello’’ 1991. Balatongyörök: 'Padkőierdő’ 2015, 'Kígyós-völgy’ 2000, 'Kerék-hegy’ 2005, 'Keserü-berek' 2014. Vállus: 'Várvölgyi-út' 1991, 'Láz-tető’ 2008, ‘Barbacs-erdő’ 2008, 'Rózsa-mező' 2009, ‘Kétfahegyi-tető' 2006, 'Képestói-putri' 2012, 'Ivány-hát' 2007, 'Szapu-völgy' 2009, 'Pórag-hát' 2017, 'Büdöskúti-arborétum' 1996, 'Büdöskúti-erdő' 2007, 'Messzi-domb' 2008. Kbm: Pat: 'Irtási-dűlő' 2016.

\section{Epipactis helleborine (L.) Crantz f. monotropoides (Mousley) Scoggan}

Zalaegerszeg-Csácsbozsok: 'Parkerdő' 1992. Bázakerettye: 'in the park of the swimming pool' 2019 (B. Á.).

KEF: 9066.4, 9067.4, 9068.1, 9069.4, 9165.4, 9165.3, 9166.1, 9166.3, 9166.4, $9167.1,9167.3,9167.4,9168.1,9168.3,9169.1,9169.2,9169.3,9169.4,9170.3$, $9264.2,9264.3,9265.1,9265.2,9265.3,9265.4,9266.1,9266.2,9266.3,9266.4$, 9267.1, 9267.3, 9268.1, 9269.2, 9270.1, 9365.1, 9365.2, 9365.4, 9366.3, 9367.3, 9465.2, 9465.4, 9466.1, 9466.2, 9466.3, 9467.1, 9467.3, 9468.1, 9468.2, 9567.1, 9567.2 , 9567.3, 9567.4, 9568.2, 9568.3, 9568.4, 9569.1, 9668.1, 9370.3. 
Epipactis helleborine (L.) Crantz subsp. minor (R. Engel) R. Engel

Habitat: oak-hornbeam forests, beech forests, mixed coniferous-oak forests.

G: Zalalövő: 'Csaló-kereszt' 2015, 'Gizella-major' 2013. Keménfa: 'Kerekdomb’ 2016. Hernyék: ‘Gyetyános’ 2012. Szilvágy: ‘Kerek-fenyves’ 2016, 'Alsóerdő' 2015, 'Kis-Zsibos' 2018. Nova: 'Lőrincfa-mellék' 2016, 'Olga-major' 2015, 'Kerta-mente’ 2017, 'Felső-hegy', 'Öreg-hegy' 2017, 'road verges' 2016. Milejszeg: 'Kis-hegy' 2018. Pördefölde: 'Pördeföldi-erdő' 2017. Bak: 'Botosi-erdő', 'Felsőhegy' 2014. ELd: Zalaegerszeg-Botfa: 'Bokáncs' 2015. Bucsuta: 'Fehérbükkierdő' 2012, 'Büki-erdő' 2014, 'Szekrényesi-oldal' 2013, 'Pörkölt-csádé' 2012, 'Alsó-erdő' 2016. Oltárc: 'Kövecses-hegyhát' 2016, 'Kútfej-erdő' 2016, 'Márkierdő' 2017, 'Horváti-erdő' 2016. Zah: Zalaszentgrót-Csáford: 'Piros-domb' 2014. Liszó: 'Medves', 'Lesházi-nyiladék' 2016. Surd: ‘Csorda-bükk' 2016. Khg: Vállus: 'Szapu-völgy' 2014. Balatongyörök: 'Keserü-berek' 2016. Mh: Hollád: 'Vadaskerti-erdő' 2016.

KEF: 9068.3, 9166.3, 9167.3, 9168.3, 9169.4, 9170.3, 9265.2, 9265.4, 9266.3, 9266.4, 9365.2, 9365.4, 9366.1, 9366.3, 9467.1, 9467.3, 9567.1, 9667.2, 9668.1, 9668.3.

Epipactis helleborine (L.) Crantz subsp. latina W. Rosii \& E. Klein

Habitat: scrub forests, thermophilous oak forests, open rocky grasslands.

Khg: Rezi: 'Pörkölt-hegyek' 2011, along 'Várvölgyi-út' 2005, 'Fagyoskereszt' 2010. Keszthely: 'Pilikári-erdő' 2009, 'Négyszögletü-hegy' 2004, 'Kis-Messzelátó' 2012, 'Nagy-Messzelátó’ 2016, 'Festetics-kilátó’ 2005, 'Kübánya,' 'Pórag-hát' 2009. Gyenesdiás: 'Nagy-Messzelátó' 2006, 'Szík-tető' 2017, 'Pórag-hát' 2009, 'Petőhegy’ 2016, 'Kesellő’ 1992. Vonyarcvashegy: 'Hosszú-völgy’ 2014. Balatongyörök: 'Pad-kői-erdő' 2015. Vállus: 'Láz-tető' 2017, 'Büdöskúti-erdő' 2010, 'Sáros-tó' 2016, 'Kétfahegyi-tető' 2012, 'Messzi-domb' 2017.

KEF: 9169.2, 9169.4, 9269.2.

Epipactis belleborine (L.) Crantz subsp. moratoria Riech. \& Zirnsack

Habitat: (sessile) oak-hornbeam forests, beech forests, hornbeam forests, birch plantations, pine plantations.

G: Zalalövő: 'Csaló-kereszt' 2009, 'Gizella-major' 2009. Nova: 'Lőrincfamellék’ 2016. FZv: Zalaegerszeg-Csácsbozsok: ‘Parkerdő’ 2010. ELd: Zalaegerszeg-Csácsbozsok: 'Bokáncs' 2015. Bucsuta: 'Büki-erdő' 2015, 'Szekrényesi-oldal' 2017.

KEF: 9167.1, 9167.3, 9265.2, 9265.4, 9467.1. 


\section{Epipactis leutei Robatsch}

Habitat: beech forests, hornbeam forests.

G: Milejszeg: 'Kis-hegy' 2018. ELd: Zalaegerszeg-Csácsbozsok: 'Bokáncs' 2010. Khg: Rezi: 'Fagyoskereszt' 2009. Vonyarcvashegy: 'Hosszú-völgy' 2014. Balatongyörök: 'Büdöskút' 2010, 'Kígyós-völgy' 2010, 'Pad-kő' 2010, 'Keserüberek’ 2014. Vállus: 'Büdöskúti-erdő’ 2014, 'Iván-hát' 2010, 'Láz-tető’ 2017, 'Ivántető' 2017.

KEF: $9166.3,9167.3,9169.4,9170.3,9269.2$.

\section{Epipactis purpurata Sm.}

Habitat: beech forests, hornbeam forests, (sessile) oak-hornbeam forests, pine-oak forests, pine plantations.

FKh: Zalaszentgyörgy: 'Pap-erdő’ 1997. G: Zalalövő: ‘Gizella-major' 2016, 'Csaló-kereszt' 2015. Salomvár: 'Gerencsér-lik' 2016. Lenti-Mumor: 'Zajdai-erdő' 2012, 'Csalános' 2012, 'Malonyai-erdő' 2012. Hernyék: 'Gálosi-nyiladék' 2012. Nova: 'Lőrincfa-mellék' 2016, 'Úrbéri-erdő' 2016, 'Cigány-fenyős' 2018. Bak: 'Botosi-erdő’ 2016, 'Nénai-erdő’ 2014. Pördefölde: 'Pördeföldi-erdő' 2017. Szentpéterfölde: 'Kis-berkes' 2016. Pusztaederics: 'Szakál-völgy' 2016, 'Szompácspuszta' 2017. Várfölde: 'Községi-erdő' 2012. Szilvágy: 'Tekeres', 'Alsó-erdő' 2016. ELd: Zalaegerszeg-Csácsbozsok: ‘Csácsi-arborétum' 1998, ZalaegerszegBotfa: 'Bokáncs' 1998. Nagykapornak: 'Kalamászos-erdo”’ 2014. Pölöske: ‘Eduárd-nyiladék' 2018, 'Bélatanya-erdö’ 2012, 'Nagy-hányási-erdő' 2012, 'Hálási-lap' 2012, 'Pölöskei-erdő' 2016, 'Kovács-hegy’ 2016. Söjtör: 'Farkas-völgy’ 2014. Hahót: 'Osztott-erdő' 2016. Zalaszentbalázs: 'Alsó-erdő' 2015. Bucsuta: 'Fehérbükki-erdő' 2012, 'Büki-erdő’ 2012, 'Szekrényesi-oldal' 2013, 'Pörkölt-csádé' 2012, 'Alsó-erdő' 2016. Oltárc: 'Kútfej-erdő’ 2016, ‘Márki-erdő’ 2017, 'Horváti-erdő' 2016. Tormafölde: ‘Vétyemi-erdő’ 1993. Zah: Zalaszentgrót-Csáford: 'Piros-domb’ 2014. Nagykapornak: 'Remetekert' 2012. Zalacsány: 'Körtvélyesi-erdő' 2012. Liszó: 'Medves' 2016, 'Lesházi-nyiladék' 2016. Khg: Vállus: 'Szent-Miklós forrás' (G. L.) 2005.

KEF: 9068.3, 9166.1, 9166.3, 9167.3, 9167.4, 9168.3, 9169.4, 9265.2, 9265.4, 9266.2, 9266.4, 9267.1, 9267.3, 9268.1, 9365.2, 9365.4, 9366.2, 9366.3, 9366.4, 9367.3, 9465.2, 9466.1, 9466.2, 9467.1, 9467.3, 9567.1, 9668.1, 9668.3.

\section{Epipactis schulzei P. Fourn. (E. helleborine $\times$ purpurata)}

Habitat: beech forests, (sessile) oak-hornbeam forests.

H: Rédics-Dedeskecskés: 'Kecskés' 1996. ELd: Bucsuta: 'Büki-erdő' 2008, 'Szekrényesi-oldal' 2008.

KEF: 9464.2, 9467.1. 


\section{Epipactis voethii Robatsch}

Habitat: beech forests, (sessile) oak-hornbeam forests, hornbeam forests.

G: Zalalövő: 'Gizella-major'. Milejszeg: 'Kis-hegy' 2018. Bak: 'Botosi-erdö' 2009. Szentpéterfölde: 'Kis-berkes' 2016. ELd: Zalaegerszeg-Botfa: 'Bokáncs' 2015. Bucsuta: 'Szekrényesi-oldal' 2013. Zah: Nagykapornak: 'Alsó-erdő' 2012, 'Remetekert' 2014. Zalacsány: 'Körtvélyesi-erdő' 2010. Zalamerenye: 'Kaniczaerdő' 2013. Kbm: Esztergályhorváti: 'Bárándpuszta' 2005 (V. R.). Khg: Rezi: 'Fagyoskereszt' 2012. Keszthely: 'Bottyán-hát' 2011, 'Pilikári-erdö’ 2009. Balatongyörök: 'Kígyós-völgy' 2007, 'Padkői-erdő’ 2007, 'Keserü-berek' 2014. Vállus: 'Rózsa-mezö’ 2017, 'Büdöskúti-erdő' 2006, 'Messzi-domb' 2006, 'Láz-tetö' 2015, 'Iván-teto”' 2014, 'Szent-Miklós forrás', 'Abrincsos-völgy' 2008, 'Szapu-völgy' 2009, 'Szent-Miklós forrás' 2009. Mh: Hollád: 'Vadaskert-erdö’ 2016.

KEF: $9167.3,9168.3,9169.3,9169.4,9170.3,9265.2,9266.2,9266.4,9268.1$, 9269.2, 9270.1, 9366.3, 9368.2, 9467.1, 9468.2, 9370.1.

\section{Epipactis kezlinekii Batoušek (E. helleborine $\times$ E. voethii)}

Habitat: beech forests, road verges.

Khg: Balatongyörök: 'Kígyós-völgy' 2007, 'Pad-kő’ 2007. Vállus: 'Büdöskútierdő' 2006.

KEF: 9169.4, 9170.3.

\section{Epipactis muelleri Godfery}

Habitat: open beech forests, scrubs, and grasslands.

ELd: Zalabér: 'Kápolnai-oldal' 2007. Zalaszentgrót-Aranyod: 'Felső-hegy' 2013. Khg: Rezi: 'Fagyoskereszt' 2009, 'Pilikáni út' 1992. Gyenesdiás: 'Pilikán' 1997, 'Tüskéslap' 1997, 'Nyilas-erdő' 1997, 'Kesellő' 2007. Lesencefalu: in quarry 1991.

KEF: 9068.1, 9068.3, 9169.4, 9170.3, 9269.2.

\section{Epipactis leptochila (Godfery) Godfery}

Habitat: beech forests, (sessile) oak-hornbeam forests, turkey oak forests.

G: Böde: 'Alsó-erdö’ 2011. Milejszeg: 'Kis-hegy' 2012. ELd: Bánokszentgyörgy: 'Vár-domb' 2012. Zah: Zalaistvánd: 'Istvándi-erdő' 2014, 'Pác-tető' 2017. Zalaszentgrót-Csáford: 'Piros-domb' 2014. Nagykapornak: 'Remetekert' 2014. Zalacsány: 'Körtvélyesi-erdő' 2010. Khg: Rezi: 'Láz-tető' 2010, 'Fagyoskereszt' 2011. Gyenesdiás: 'Kis-Láztető' 2017. Vonyarcvashegy: ‘Büdöskúti-út' 2008. Balatongyörök: 'Büdöskúti-arborétum' 2008, 'Padkői-erdő' 2008, 'Kis-Püspökházvölgy’ 2012. Vállus: ‘Borjazó-domb’ 2017, ‘Büdöskút' 2010. 
KEF: $9067.4,9068.3,9166.3,9168.3,9169.3,9169.4,9170.3,9268.1,9269.2$, 9467.3.

\section{Epipactis neglecta (Kümpel) Kümpel}

Habitat: beech forests, pine-oak forests, pine forests, scrub forests.

G: Lenti-Bárszentmihályfa: 'Zajdai-erdő' 1998, 'Csalános' 2000. Hernyék: 'Gálosi-nyiladék' 2000. Szilvágy: 'Alsó-erdő’ 2012. Nova: 'Lőrincfa-mellék’ 2016, 'Olga-major' 2016. Gombosszeg: ‘Csarit' 2015. Bak: 'Botosi-erdő’ 2012. ELd: Petőhenye: 'Csillag-hegy' 2010, 'Alsó-erdo’’ 2012. Zalaegerszeg-Csácsbozsok: ‘Csácsi-erdo’’ 2010. Zalaegerszeg-Botfa: ‘Bokáncs' 2010. Nagykapornak: 'Körtvélyesierdő’ 2016, 'Kalamászos-erdo’’ 2011 (†). Pölöske: 'Féligbaki-erdő' 2015. Bucsuta: 'Fehérbükki-erdő' 2012, 'Szekrényesi-oldal' 2013. Tormafölde: 'Vétyemi-erdő'. Oltárc: 'Vár-domb' 'Márki-erdő' 2015. Eszteregnye-Obornak: 'Várbükki-erdő' 2010, 'Szorosos' 2010. Lasztonya: 'Erdőháti-erdő' 2016. Tormafölde: 'Vétyemibükkös' 2016. Zah: Zalaistvánd: 'Istvándi-erdő', 'Pácz-tető'. Zalaszentgrót-Csáford: 'Piros-domb'. Nagykapornak: 'Bánfai-erdő' 2012, 'Remetekert' 2010. Zalacsány: 'Körtvélyesi-erdő' 2012. Nemesrádó: 'Büki-erdő' 2012. Újudvar: 'Korágó’ 2012. Zalamerenye: 'Kanicza-erdő' 2012. Mh: Hollád: 'Vadaskert-erdő' 2016.

KEF: 9068.3, 9167.1, 9167.3, 9167.4, 9168.3, 9265.4, 9266.1, 9266.2, 9267.3, 9268.1, 9365.2, 9365.4, 9465.2, 9466.1, 9467.1, 9467.3, 9468.2, 9468.3, 9370.1.

\section{Epipactis nordeniorum Robatsch}

Habitat: beech forests, hornbeam forests, (sessile) oak-hornbeam forests, pine plantations.

FZv: Zalaegerszeg-Csácsbozsok: 'Parkerdő' 2009. H: Csöde: 'Farkas-lik' 2011. G: Kerkafalva: ‘Ritás’ 2004, ‘Szattai-patak’ 2004. Kerkakutas: ‘Árkosi-erdő' 2011. Kálócfa: 'Mihom’ 2009. Zalalövő: 'Laki-erdő’ 2009, ‘Gizella-major’ 2009. Zalaegerszeg: 'Alsó-erdő’ 2010. Gellénháza: 'Pipa-hegy’ 2009. Nagylengyel: ‘Kellő-híd’ 2008. Bak: 'Botosi-erdo’’ 2012, ‘Nénai-erdő' 2006. Szilvágy: ‘Kerek-fenyves' 2011. Nova: 'Lőrincfa-mellék' 2009. Lendvadedes: 'Nagyistók-erdő' 2005. Lenti-Mumor: 'Csalános' 2008. Hernyék: 'Gálosi-nyiladék' 2011. Pördefölde: 'Pördeföldi-erdő’ 2011. Bánokszentgyörgy: 'Keresztesi-erdő' 2012. Pusztaederics: 'Szakál-völgy' 2012. ELd: Zalaegerszeg-Csácsbozsok: 'Csácsi-arborétum' 2006, 'Csácsi-erdő' 2009. Zalaegerszeg-Botfa: 'Bokáncs' 2012. Nagykapornak: 'Körtvélyesi-erdő' 2016. Csatár: 'Pusztika' 2009, 'Remete' 2009. Pölöske: 'Eduárdnyiladék' 2018, 'Béla-tanya-erdő' 2012, 'Nagy-hányási-erdő’ 2018. Pusztamagyaród: 'Alsó-erdő' 2016. Söjtör: 'Barátpuszta' 2004 (†). Hahót: 'Osztott-erdő' 2016, 'Miska' 2001 (†). Bucsuta: 'Büki-erdő' 2012, 'Szekrényesi-oldal' 2009, 'Alsóerdő’ 2009. Oltárc: ‘Horváti-erdő’ 2016. Eszteregnye-Obornak: 'Várbükki-erdő', 
'Szorosos' 2010. Tormafölde: 'Vétyemi-erdő' 2016. Zah: Zalaszentgrót-Csáford: 'Piros-domb' 2014. Padár: 'Felső-erdő’ 2011. Almásháza: 'Almásházi-erdő' 2016. Zalacsány: 'Körtvélyesi-erdő' 2009. Zalamerenye: 'Kanicza-erdő' 2018. Liszó: 'Medvés' 2016. Kbm: Esztergályhorváti: 'Bárándpuszta' 2005. Mh: Hollád: 'Vadaskert-erdő' 2016.

\section{Epipactis nordeniorum Robatsch f. chlorotica Kohns \& Schneider}

ELd: Zalaegerszeg-Csácsbozsok: 'Csácsi-arborétum' 2004.

KEF: 9068.3, 9165.4, 9165.3, 9166.4, 9167.3, 9168.1, 9168.3, 9264.2, 9265.1, 9265.2, 9265.3, 9266.2, 9266.3, 9266.4, 9267.1, 9267.3, 9268.1, 9365.4, 9366.3, 9366.4, 9367.3, 9368.2, 9465.1, 9465.2, 9466.2, 9467.1, 9467.3, 9468.2, 9569.3, 9668.1, 9370.1.

\section{Epipactis tallosii A. Molnár \& Robatsch}

Habitat: beech forests, hornbeam forests, (sessile) oak-hornbeam forests, pine plantations.

FKh: Vaspör: 'Aszottasi-dűlő' 2008. H: Rédics: ‘Töllösi-erdő' 2008. RédicsLendvadedes: 'Nagyistók-erdő' 2005. G: Zalalövő: 'Nagyhegy-puszta' 2011, 'Gizella-major' 2009. Böde: 'Cseresnyés' 1995. Milejszeg: 'Csarit' 2011, 'Kis-hegy' 2011, 'Gesztenyés' 2010. Kustánszeg: 'Kertesi-dủlő’ 2011. Becsvölgye-Kislengyel: 'Horvát-ház' 2010. Zalabaksa: 'Pap-kút' 2007. Szilvágy: 'Orbán-lap' 2009, 'Alsóerdő' 2016, 'Felső-erdő' 1992, 'Kis-Zsibos' 2016. Nova: 'Lőrincfa-mellék' 2009, 'Olga-major' 2000, 'Kondorai-erdő' 2006. Lickóvadamos: ‘Csöpögő’ 2013. Bak: 'Botosi-erdő’ 2008, 'Nénai-erdő' 2006. Baktüttős: ‘Gyertyános' 2009. Pördefölde: 'Pördeföldi-erdo’' 2003. Szentpéterfölde: 'Szálas-erdő' 2011, 'Kis-berkes' 2003, 'Hosszú-hegy' 2012. Várfölde: 'Községi-erdő' 2012. Bánokszentgyörgy: 'Keresztesi-erdő' 2012. ELd: Kemendollár-Kemend: 'Körtefa-dülo’' 2010, 'Csácsi-arborétum' 2004, 'Csácsi-erd”’' 2006. Zalaegerszeg-Botfa: 'Bokáncs' 2009. Alsónemesapáti: 'Átó-faludi-erdő' 2010 (†), 'Padalja' 2010 (†). Nemesapáti: 'Hosszúbükk', 'Bucsai-erdő' 2005. Nagykapornak: 'Körtvélyesi-erdő' 2010, 'Kalamászoserdő' 2010 (†). Csatár: 'Bükk-alja' 2009, 'Pusztika' 2009, 'Remete’ 2009. Pölöske: 'Eduárd-nyiladék' 2009, 'Hálási-lap' 2006, 'Bük-tetô’ 2008. Hahót: 'Osztott-erdő' 2010. Bucsuta: 'Büki-erdő' 2009, 'Szekrényesi-oldal' 2009. Oltárc: 'Kútfej-erdö' 2009. Eszteregnye-Obornak: 'Várbükki-erdő' 2010, 'Szorosos' 2008, forester's lodge 2010, 'Gyurkáncsi-erdő' 2010. Valkonya: 'Úrbéresi-erdo’' 2011. Becsehely: 'Barkóczás' 2011. Tormafölde: 'Vétyemi-erdő' 2006. Dobri: 'Hegyvámos' 2006. Bánokszentgyörgy: 'Haraszti-erdö' 2008. Csörnyeföld: 'Vörcsöki-erdö' 2006. Páka-Dömefölde: 'Fejérlakosa-erdő' 2010. Zajk: 'Északi-erdő' 2008. Zah: Bezeréd: 'Felső-erdő' 2016. Padár: 'Felső-erdő' 2011, 'Hamuházi-tábla' 2011. 
Nagykapornak: 'Remetekert' 2010. Zalacsány: 'Körtvélyesi-erdő' 2009. Nagykanizsa: 'Felső-erdő' 2009 (F. S.). Nagyrécse: 'Alsó-erdő’ 2009 (F. S.). Miháld: 'Muszinadóla' 2009 (F. S.). Liszó: 'Medvés' 2016, 'Lesházi-nyiladék' 2016. Kbm: Esztergályhorváti: 'Bárándpuszta' 2005. Mh: Hollád: 'Vadaskert-erdő’ 2016.

KEF: 9165.4, 9165.3, 9166.1, 9166.3, 9166.4, 9167.2, 9167.3, 9167.4, 9168.1, $9168.2,9168.3,9169.4,9170.3,9265.2,9265.3,9265.4,9266.2,9266.3,9266.4$, $9267.1,9267.3,9268.1,9269.2,9365.3,9365.4,9366.3,9366.4,9367.3,9368.2$, 9464.2, 9465.1, 9465.2, 9465.4, 9466.1, 9466.2, 9466.3, 9466.4, 9467.1, 9467.3, $9468.1,9565.2,9566.2,9568.1,9568.4,9668.1,9668.3,9370.1$.

Epipactis pontica Taubenheim

Habitat: beech forests, hornbeam forests, (sessile) oak-hornbeam forests.

FKh: Vaspör: 'Velence-hegyi-erdő' 2008. Zalaszentgyörgy: 'Templom-erdő' 2013. FZv: Zalaegerszeg-Csácsbozsok: 'Parkerdő' 2012. H: Csöde: 'Farkas-lik' 2011. Rédics-Lendvakecskés: 'Kecskés', 'Sándor-gesztenyés' 2005. G: Zalalövő: 'Kecske-hát' 2018, 'Nyerges' 2011, 'Laki-erdő' 2015. Keménfa: 'Kerek-domb’ 2016. Zalaegerszeg: 'Alsó-erdő' 2006. Becsvölgye: 'Buhás' 2016, 'Kis-bükkös' 2016. Becsvölgye-Kislengyel: 'Horvát-ház' 2010. Milejszeg: 'Kis-hegy' 2011. Nova: 'Lőrincfa-mellék' 2009, 'Úrbéri-erdő' 2016. Pördefölde: 'Pördeföldi-erdő’ 2011. Szentpéterfölde: 'Kis-berkes’ 2017. Várfölde: 'Községi-erdő' 2014. Lasztonya: 'Erdőháti-erdő' 2016. Szilvágy: ‘Alsó-erdő’ 2016, 'Kis-Zsibos' 2016, 'Kerek-fenyves' 2016, 'Mutatófa' 2009 (†). Bak: 'Botosi-erdo’' 2014. ELd: Zalaegerszeg-Csácsbozsok: ‘Csácsi-arborétum' 2006, ‘Csácsi-erdő’ 2006. Zalaegerszeg-Botfa: ‘Bokáncs' 2010. Alsónemesapáti: 'Padalja' 2010. Nagykapornak: 'Kalamászos-erdő' 2010. Pölöske: 'Eduárd-nyiladék' 2018, 'Béla-tanya-erdő’ 2012, 'Féligbaki-erdő' 2009, 'Kovács-hegy' 2016. Hahót: 'Osztott-erdő' 2016. Bucsuta: 'Fehérbükki-erdő’ 2012, 'Büki-erdő’ 2012, 'Szekrényesi-oldal' 2013, 'Pörkölt-csádé' 2012, 'Kútfej-erdő' 2009. Oltárc: ‘Kútfej-erdő’ 2009, 'Vár-domb’ 2012, ‘Horváti-erdő’ 2016. Eszteregnye-Obornak: 'Zsindelyes' 2008. Valkonya: 'Úrbéresi-erdő' 2011. Becsehely: ‘Barkóczás' 2011. Iklódbördőce: ‘Csokmai-erdő’ 2016. Tormafölde: 'Vétyemi-erdo’' 2006. Lasztonya: 'Erdőháti-erdő' 2016. Zajk: 'Északi-erdő' 2008. Zah: Padár: 'Hamuházi-tábla' 2011. Almásháza: 'Almási-erdő' 2016. Nagykapornak: 'Bánfai-erdő' 2007, 'Remetekert' 2010. Zalamerenye: 'Kanicza-erdo’’ 2013. Kbm: Esztergályhorváti: 'Bárándpuszta' 2005.

KEF: 9066.3, 9165.4, 9165.3, 9166.1, 9166.3, 9166.4, 9167.3, 9167.4, 9168.1, $9168.2,9168.3,9264.2,9265.2,9265.4,9266.1,9266.2,9266.3,9266.4,9267.1$, 9267.3, 9268.1, 9365.2, 9365.4, 9366.3, 9366.4, 9367.3, 9368.2, 9464.2, 9465.1, 9465.2, 9466.1, 9466.2, 9466.4, 9467.1, 9467.3, 9468.2, 9566.2. 


\section{Epipactis moravica Batušek}

Habitat: (sessile) oak-hornbeam forests.

Khg: Vállus: 'Büdöskúti-erdő’ 2013. Mh: Hollád: 'Vadaskert-erdo’' 2016 (R. Gy.).

KEF: 9169.4, 9370.1.

\section{Epipactis peitzii $\mathrm{H}$. Neumann \& Wucherpf.}

Habitat: beech forests, hornbeam forests, (sessile) oak-hornbeam forests.

Khg: Rezi: 'Láz-tető' 2008, 'Pörkölt-hegyek' 2016, 'Pap-út' 2008, 'Fagyoskereszt' 2015. Balatongyörök: 'Padkői-erdo’' 2015, 'Kígyós-völgy' 2010, 'Boncsostető' 2014, 'Pad-kő' 2007, 'Keserü-berek' 2014, 'Vékony-cser' 2016. Vállus: 'Messzidomb' 2008, 'Büdöskúti-erdő' 2006. Lesencefalu: 'Köves-völgy' - 'Fagyos-út' 2016.

KEF: 9169.2, 9169.3, 9169.4, 9170.3, 9269.2.

\section{Epipactis helleborine $\times$ peitzii}

Habitats: beech forests.

Khg: Rezi: 'Fagyoskereszt' 2015.

KEF: 9169.4

\section{Limodorum abortivum (L.) Sw.}

Habitats: beech forests, scrub forests, thermophilous oak (Quercus pubescens) forests, black pine plantations.

Khg: Cserszegtomaj: ‘Gyötrös-tető' 2009. Rezi: ‘Dino-park' 2010 (†). Vállus: 'Kétfahegyi-tető' 2016. Keszthely: 'Pilikáni-út' 1997, 'Pilikáni-erdő' 2009, 'Négyszögü-hegy' 1993, 'Festetics-kilátó' 2005, 'Kübánya' 2009, 'Nagy-Messzelátó' 1995. Gyenesdiás: 'Pilikán' 1997, 'Meleg-hegy' 1995, 'Lakatos-hegy' 1993, 'Nyilas-erdo’' 1997, 'Pórag-hát' 1993, 'Kis-Messzelátó' 1997, 'Nagy-Messzelátó’ 2009, 'Öreg-Szék-tető’ 1997, 'Ló-hegy' 1995, ‘Petö-hegy' 1993, 'Berzsenyi-kilátó’ 1995, 'Tüskéslap' 1992, 'Kesellő' 1997. Vonyarcvashegy: 'Vonyarci-fenyves' 2019, 'Vonyarci-cser' 2019, 'Malacos-tető' 2019, 'Kitaibel-kilátó', 'Vas-hegy', 'Csalánosvölgy’. Balatongyörök: 'Vashegyi-erdő’ 2019, 'Gotthárdsík-tető' 2019, 'Paphegyiugrató’ 2017.

KEF: $9169.3,9169.4,9269.2,9270.1$.

Spiranthes spiralis (L.) Chevall.

Habitat: mountain hay meadows, open rocky grasslands, steppes, orchards, chestnut plantations, cemeteries. 
FKh: Vaspör: 'Takács-domb' 2007. Vaspör-Velence: sports court, meadows, orchards of the village 2009. Zalaháshágy: 'Öreg-hegy' 2010, 'Bakos-hegy' 2010, 'Alsó-hegy' 2010. Zalacséb: 'Román-hegy' 2007, 'Öreg-hegy' 2007, 'Gesztenyés-hegy' 2010. Egervár: 'Csillag-hegy' 1991. Gösfa: 'Gős-hegy' 1990. H: Csöde: in cemetery 2014. Kerkakutas: in cemetery 2009. Felsőszenterzsébet: in orchards 2004. Alsószenterzsébet: in cemetery 2009. Szentgyörgyvölgy: 'Templom-domb' 1995. G: Keménfa: 'Keresztúri-puszta' 2009. Boncodfölde: 'Kéthegy-közt' 2017, 'Nagyhegy' 2004. Németfalu: 'Kis-hegy' 2007. Hottó-Zalaszentmihályfa: 'Pergyászlóihegy' 1991, 'Szentmihály-hegy' 2006. Milejszeg: 'Lóka-hegy' 2007, in cemetery 2009, 'Gesztenyés-hegy' 2007. Kustánszeg-Parasza: 'Konku' 2009. BecsvölgyeKislengyel: in cemetery 2007, 'Gödörháza' 2010. Becsvölgye-Pajzsszeg: in orchards 2015. Ormándlak: 'Laki-hegy' 2007. Gombosszeg: in orchards and meadows 2015. Pórszombat: in cemetery 2009. Szilvágy: 'Határ-hegy' 1998, in cemetery 2009, 'Nagy-hegy' 2009. Petrikeresztúr: 'Pató-hegy' 2008. Kerkabarabás: 'Cser-hegy' 2009. Hernyék: in cemetery 2014. Pusztaederics: 'Belső-hegy' 2007, 'Új-hegy' 2007. ELd: Zalaegerszeg-Csácsbozsok: 'Mándi-domb' 1995. Csatár: 'Kincsem-hegy' 1991. Pölöske: 'Öröm-hegy' 2015. Nemessándorháza: 'Kü-hegy' 2002. Kiscsehi: 'Tekintshegy' 2004. Csörnyeföld: 'Vörcsöki-erdő' 2004. Szentmargitfalva: in meadow 2004. Borsfa: 'Róka-hegy' 1991. Muraszemenye: 'Csányi-hegy' 1996. Zah: Zalaköveskút: 'Kis-hegy' 1997. Khg: Várvölgy: 'Bándi-mezo’' 1998. Vállus: 'Várvölgyi-út' 1991. Kbm: Balatonszentgyörgy: 'Szentgyörgyi-legelö' 1993 (P. S.).

KEF: 9065.4, 9067.1, 9067.3, 9165.4, 9165.2, 9165.3, 9166.1, 9166.3, 9166.4, 9167.3, 9168.2, 9169.2, 9169.4, 9264.2, 9264.4, 9265.1, 9265.3, 9265.4, 9266.1, 9266.3, 9267.1, 9267.2, 9365.1, 9365.4, 9366.1, 9366.4, 9465.4, 9466.3, 9565.2, 9566.2, 9568.3 .

\section{Orchis militaris L.}

Habitat: steppes, fens, fallows, secondary Molinia meadows, scrub forests, thermophilous oak (Quercus pubescens) forests, orchards, chestnut plantations.

FKh: Egervár: 'Csillag-hegy' 1993, 'Kövecses-alja' 1992. Gösfa: 'Vitárgya' 1995. FZv: Zalaegerszeg-Pózva: 'Nagy-rét' 2011. G: Böde: 'Nagy-Varjas' 2016. Ms: Tornyiszentmiklós: 'Újfalui-hegy' 2001. ELd: Zalaistvánd: 'Barkus-hegy' 2009. Kemendollár: 'Kápolnai-dűlő' 2004, 'Közép-dűlo’' 2004, 'Almás-dűlő' 2011, 'Kemendi-hegy' 2005, 'Csertói-dűlo’' 2009. Vöckönd: 'Bagó-hegy' 2004. Petőhenye: 'Cigány-hegy' 1996, 'Tót-hegy' 1991, 'Torma-hegy' 1990, 'Sziácsmány' 2017, 'Avashegy' 1991, 'Csillag-hegy' 2005, 'Alsó-erdő' 2005. Nemesapáti: 'Kis-Újhegy' 2008, 'Csertó-hegy' 2008. Alsónemesapáti: 'Átó-faludi-erdő' 2005 (†), 'Belső-hegy' 1994, 'Nagy-Újhegy' 2015. Zalaegerszeg-Csácsbozsok: 'Csácsi-hegy' 2005, 'Bozsokidomb’ 1995, 'Csácsi-erdő' 2005. Kisbucsa: 'Hosszú-hegy’ 2005 (†). Misefa: 'Mi- 
sefai-hegy' 1999. Csatár: 'Kismező' 2013. Nemessándorháza: 'Szoboszlói-berek' 1993, 'Szivácsi-dűlő' 2009, 'Szoboszlói-dűlő' 2005, 'Szoboszlói-hegy' 1995. Zalaszentmihály: 'Koldus-hegy’ 1997. Hahót: 'Júlián-hegy’ 2013. Páka-Dömefölde: 'Kányavári-hegy' 2004. Szécsisziget: 'Szigeti-hegy' 2001. Szentmargitfalva: 'Öreg-hegy' 1996. Muraszemenye: 'Csányi-hegy' 1996. Maróc: 'Maróci-hegy' 2004, 'Temetői-oldal' 2005. Lispeszentadorján: 'Szentadorjáni-hegy' 2014. Bázakerettye: 'Szociális otthon' 2011 (B. Á.). Bánokszentgyörgy: 'Külső-hegy' 2006. Prv: Füzvölgy: 'Osztott-rétek' 2014, 'Berki-rétek' 1991 (P. S.). Nagykanizsa: 'Császárrét' 1991. Sormás-Nagykanizsa: 'Gördövény' 1994. Szepetnek: 'Cerinaerdo’' 2008 (H. T.). Zah: Zalabér: 'Kápolnai-oldal' 2015, 'Teke-völgy' 2006. Zalaszentgrót: 'Bagó-völgy' 1995, 'Felső-Aranyod' 2005. Zalaszentgrót-Csáford: 'Felső-hegy' 2014, 'Som-tető' 2014, 'Bodókai-dülő' 2005, 'Boggos-domb' 2005, 'Deják-föld' 2011. Bezeréd: 'Bezerédi-hegy' 2004. Zalaszentgrót-Zalakoppány: 'Deják-föld' 2011, 'Rátka-hegy' 2016, 'Szíj-völgy' 2011. Kallósd: 'Új-hegy' 2005, 'Öreg-hegy' 1996. Kehidakustány-Barátsziget: 'Csoma-tető' 2005, 'Öreg-hegy' 2005. Almásháza: 'Fábián-hegy' 2000. Nemesrádó: 'Rádi-hegy' 2005. Tilaj: 'Zombor-hegy' 1995. Szentpéterúr: 'Szabad-hegy' 2012. Zalaapáti: 'Öreg-hegy' 2006. Dióskál: 'Ungi-hegy' 1996, 'Öreg-hegy' 1996, 'Szegfalusi-hegy' 2009, 'Pogányvár' 2006, 'Közép-hegyhát' 2009. Kerecseny: 'Új-hegy' 2007, 'Török-csapás' 2008, 'Fehér-hegy' 2007. Orosztony: 'Vajda-kút' 2006. Gelse: 'Szoros-hegy' 2008. Nagybakónak: 'Pakarics-hegy' 2010. Újudvar: 'Dalasi-hegy' 2012. AZv: Batyk: 'Síki-rét' 1991, 'Zala-mellék' 2009. Zalaszentgrót-Tüskeszentpéter: 'Dombosrét' 2005. Zvh: Zalaszentgrót: 'Bujtor-domb' 2010, 'Pityer-domb' 1995. Zalaköveskút: 'Kis-hegy' 1990, 'Gesztenye-hegy' 2011. Tcs: Várvölgy: 'Mulató' 2009. Lesenceistvánd: 'Csengő' 2015, 'Kö-orra' 1996. Lesencetomaj: 'Csuhus-rét' 1992. Tm: Tapolca: 'Viszló-mente' - airport 1989. Khg: Rezi: 'Meleg-hegy' - 'Rezi-vár' 2016. Keszthely: 'Négyszögü-hegy' 1994. Gyenesdiás: 'Kis-Messzelátó' 1997, 'Pórag-hát' 1995, 'Tüskéslap' 1993. Kbm: Zalavár: on the embankments of river Zala 1998 (F. S.), Balatonmagyaród: 'Hídvégpuszta' 2018 (T. M.).

\section{Orchis militaris L. f. alba Löhr.}

ELd: 'Kemendi-hegy' 2015. Vöckönd: 'Bagó-hegy' 2005. Nemessándorháza: 'Szoboszlói-berek' 1993. Prv: Füzvölgy: 'Osztott-rétek' 1993 (P. S.). Prv: Nemesrádó: 'Rádi-hegy' 2005.

KEF: 9067.1, 9067.2, 9067.3, 9067.4, 9068.1, 9068.3, 9068.4, 9166.3, 9167.1, $9167.2,9167.3,9167.4,9168.1,9168.2,9168.3,9169.2,9169.4,9170.1,9170.2$, 9267.1, 9267.2, 9268.1, 9268.4, 9269.2, 9269.3, 9269.4, 9367.3, 9368.1, 9368.2, 9368.3, 9368.4, 9369.2, 9369.3, 9465.2, 9465.3, 9466.1, 9466.3, 9466.4, 9467.4, 9468.1, 9468.3, 9565.2, 9566.1, 9567.2, 9567.3, 9667.4. 


\section{Orchis purpurea Huds.}

Habitat: steppes, fens, fallows, scrub forests, thermophilous oak (Quercus pubescens) forests, orchards, chestnut plantations, beech forests, (sessile) oakhornbeam forests.

FKh: Egervár: 'Kápolnai-domb’ 2013. Gösfa: ‘Gösfai-hegy’ 2004. H: Tornyiszentmiklós: ‘Öreghegy-kápolna' 1998. G: Zalaegerszeg: 'Alsó-erdő’ 1990 (Sz. L.). ELd: Kemendollár: 'Kápolnai-dűlő’ 2011, 'Kemendi-hegy' 1995, 'Almás-dűlő' 2006. Vöckönd: 'Bagó-hegy' 2011. Zalaszentiván: 'Csortán’ 1993. Petőhenye: 'Magasmán' 1993, 'Malom-domb’ 1990, 'Köszörűs' 2017, ‘Alsó-erdő' 2005, 'Unthegy’ 2011, 'Avas-hegy' 2011. Nemesapáti: ‘Csertó-hegy’ 2008. Alsónemesapáti: 'Avas-dűlö' 2011, 'Zsidó-hegy' 1994. Zalaegerszeg-Csácsbozsok: 'Bozsokidomb' 1994. Zalaegerszeg-Botfa: 'Felső-erdő' 1998, 'Bokáncs-dűlő' 2013. Csatár: 'Pusztika' 1995 (P. S.). Kisbucsa: 'Kopasz-hegy' 1998. Nagykapornak: 'Körtvélyesi-erdő' 1994. Pölöske: 'Öröm-hegy' 2013, 'Kis-hegy' 2015, 'Hálásilap’ 2016. Nemessándorháza: 'Szoboszlói-hegy' 2013, 'Kü-hegy' 1994. Magyarszerdahely: 'Szerdahelyi-hegy' 2008. Páka-Dömefölde: 'Kányavári-hegy' 1996, 'Fejérlakosai-erdő' 1996. Maróc: 'Maróci-hegy' 2004, 'Temetői-oldal' 2008. Bánokszentgyörgy: 'Rigó-hegy'. Zah: Zalaszentgrót-Csáford: 'Csernak' 2015, 'Piros-domb' 2000, 'Felső-hegy’ 2011, 'Aszó-tető’ 2013. 'Balog-völgy' 2011.Zalaszentgrót-Zalakoppány: 'Rátka-hegy' 1999. Zalaistvánd: 'Pácz-tető' 2000. Bezeréd: 'Bezerédi-hegy' 1997. Kallósd: 'Új-hegy' 1996. Nagykapornak: 'Hársasaljaidűlő’ 2010. Zalacsány: 'Meleg-hegy’ 1997. Nemesrádó: ‘Rádi-hegy' 1995. Szentpéterúr: 'Új-hegy' 2012. Dióskál: 'Ungi-hegy' 2005, 'Gesztenyés’ 2013, 'Bükk-lap' 2005, 'Káli-hegy' 2013, 'Arany-kút' 2005, 'Öreg-hegy' 2009, 'Pogányvár' 1996, 'Szegfalusi-hegy' 2009. Egeraracsa: 'Kismező' 1996. Kerecseny: 'Lujza-hegy' 2002, 'Török-csapás' 2008, 'Új-hegy' 2007, 'Bagácsa' 2008. Gelse: 'Szoros-hegy' 2008. Nagybakónak: 'Pakarics-hegy’ 2017. Zvh: Zalaszentgrót: 'Huszonya’ 2011. Sénye: 'Új-hegy' 2007, 'Hosszú-föld' 2007. Zalaszentlászló: 'Gyülevészi-puszta' 2007. Kehidakustány-Kustány: 'Papucs-hegy' 1990. Zalaköveskút: 'Kis-hegy' 2008, 'Gesztenye-hegy' 2011. Tcs: Lesenceistvánd: 'Kő-orra' 1996. Khg: Cserszegtomaj: 'Gyötrös'. Rezi: 'Hosszú-hegy' 2010, 'Meleg-hegy' 2007, 'Rezi-vár' 2005, 'Bányafö-tető' 2011, 'Pajta-völgy’ 2011, 'Mély-völgy' 2011, 'Pörkölt-hegyek' 2011, 'Láz-tető’ 2008, ‘Kozma-tető' 2008. Vállus: ‘Borjazó-domb’ 2010, 'Barbacserdő', 'Láz-tető' 2009, 'Somos-tető' 2008, 'Iván-hát' 2009, 'Messzi-domb' 2009, 'Kétfahegyi-teto”’ 2011, 'Képestói-putri’ 2017, 'Rózsa-mező' 2011. Keszthely: 'Kő-hát' 2018, 'Csóka-kő’ 2010, 'Csorna-kúti-völgy' 2016, ‘Tömlöc-hegy' 2001, 'Négyszögü-hegy' 2007, 'Festetics-kilátó' 2012, 'Pilikáni-út' 1996. Gyenesdiás: 'Nagy-Messzelátó’ 2017, 'Kis-Messzelátó' 1997, 'Szík-tető' 2017, 'Meleg-hegy' 1997, 'Kö-mell’ 1993 (P. S.), 'Varsás-hegy’ 2018, ‘Tüskéslap’ 2006, 'Nyilas-erdő’ 
1995, 'Kesello’' 2009, 'Öreg-Szék-tető' 1995, 'Pajta-völgy' 2005, 'Berzsenyi-kilátó’ 1997. Vonyarcvashegy: 'Vonyarci-fenyves' 1991, 'Vas-hegy' 2019, 'Vonyarci-cser' 2019, 'Hosszú-völgy' 2019, 'Malacos-tető' 2019, 'Csalános-völgy' 2019. Balatongyörök: 'Csereze-hegy' 2019, 'Vashegyi-erdo’' 2019, 'Padkő-erdo’' 2006, 'Boncsostető' 2014, 'Kerek-hegy' 2005, 'Paphegyi-ugrató' 2013, 'Bece-föle’ 2008. Balatonederics: 'Sipos-torok' 2013. Lesencefalu: ‘Gesztenyés' 1991, 'Nagy-domb' 1989.

Orchis purpurea Huds. f. alba Löhr.

ELd: Kemendollár: 'Kemendi-hegy' 2010. Zah: Dióskál: ‘Ungi-hegy' 2005.

KEF: 9067.1, 9067.2, 9067.3, 9067.4, 9068.1, 9068.3, 9068.4, 9166.4, 9167.1, 9167.2, 9167.3, 9167.4, 9168.1, 9168.2, 9168.3, 9168.4, 9169.1, 9169.2, 9169.3, 9169.4, 9170.1, 9170.3, 9267.1, 9267.2, 9268.1, 9269.2, 9270.1, 9368.1, 9368.3, 9465.1, 9465.2, 9466.1, 9466.4, 9467.3, 9468.1.

Orchis $\times$ hybrida (Lindl.) Boenn. ex Rchb.

Habitat: steppes, fallows, secondary Molinia meadows.

ELd: Kemendollár: 'Kemendi-hegy' 2005. Zalaegerszeg-Csácsbozsok: 'Bozsoki-domb' 2012. Zalaszentmihály: 'Koldus-hegy' 1995. Maróc: 'Maróci-hegy' 2013. Páka-Dömefölde: 'Kányavári-hegy' 1996. Zah: Bezeréd: 'Bezerédi-hegy' 2011. Nemesrádó: 'Rádi-hegy' 1993. Dióskál: 'Pogányvár' 2009, 'Közép-hegyhát'. Egeraracsa: 'Kismező' 1996, Kerecseny: 'Fehér-hegy’ 2008. Zvh: KehidakustányKustány: 'Papucs-hegy' 1996.

KEF: 9167.2, 9167.3, 9168.1, 9168.2, 9267.2, 9268.1, 9368.1, 9368.3, 9465.2, 9466.1.

\section{Orchis mascula subsp. signifera (Vest.) Soó}

Habitats: chestnut plantations.

Khg: Lesenceistvánd: ‘Csengő’ 2015.

Orchis mascula subsp. signifera f. alba Giran - together with the previous one KEF: 9170.1.

\section{Orchis pallens L.}

Habitat: limestone beech forests

Khg: Vállus (B. N.).

KEF: 9169.3. 


\section{Platanthera bifolia (L.) Rich.}

Habitat: beech forests, hornbeam forests, (sessile) oak-hornbeam forests, scrub forests, thermophilous oak (Quercus pubescens) forests, limestone beech forests, alkaline fens.

FKh: Ozmánbük: 'Gelegenyés' 1990. Zalaszentlőrinc: 'Tölgyes' 1990. H: Magyarföld: 'Berki-hegy' 2008. Lenti: shooting range at 'Bárszentmihályfa'. Rédics-Lendvakecskés: 'Kecskés' 2005, 'Kelekút' 2005, 'Sándor-gesztenyés' 2005, 'Töllösi-erdő' 2008. G: Zalalövő: 'Pacsa-erdő' 1995, 'Nyerges' 2011, ‘Csaló-kereszt' 2009. Zalaegerszeg: 'Alsóerdő' 1995. Kerkakutas: ‘Tótok-fenyőse’ 2006. Kozmadombja: 'Ispányi-sűrü' 2006. Pusztaapáti: 'Szőlőföldi-oldal' 1992. Szilvágy: 'Határ-hegy', 'Cseri-dűlő', 'Kerek-fenyves' 2011, 'Mutatófa' 2018. Becsvölgye: 'Buhás' 2011. Lenti-Mumor: 'Csalános' 1996. Nova: 'Kondorai-erdő' 2006. Pördefölde: 'Pördeföldi-erdő' 2011. Szentpéterfölde: 'Kis-berkes' 2017. Várfölde: 'Községierdő' 2014, 'Kis-tölles'. Bánokszentgyörgy: 'Keresztesi-erdő' 2012. ELd: Petőhenye: 'Avas-hegy' 1997, 'Alsó-erdő' 2016. Zalaegerszeg-Csácsbozsok: 'Csácsi-erdö’ 1995, 'Csácsi-arborétum' 1995. Zalaegerszeg-Botfa: 'Bokáncs' 1995. Nagykapornak: 'Kalamászos-erdő’ 2010. Misefa: 'Misefai-hegy’ 1998. Pölöske: ‘Bélatanya-erdö' 2011, 'Hálási-lap' 2012, 'Nagy-hányási-erdő' 2018, 'Ökör-tilosi-erdö' 1991. Hahót: 'Osztott-erdő' 2016. Bucsuta: 'Bán-kürtős' 2015, 'Fehérbükki-erdő' 2008, 'Szekrényesi-oldal' 2008, 'Alsó-erdő' 2009. Zalaszentbalázs: 'Alsó-erdő' 2015. Oltárc: 'Kútfej-erdő' 2016, 'Horváti-erdő' 2016, 'Vár-domb' 2012. Eszteregnye-Obornak: 'Zsindelyes' 2012, 'Várbükki-erdő' 2012, 'Szorosos' 2008. Bánokszentgyörgy: 'Haraszti-erdő' 2008. Kistolmács: 'Körvélyes' 2010. Zajk: 'Északi-erdő' 2008. Murarátka: 'Rátkai-erdő' 1997. Csörnyeföld: 'Vörcsöki-erdő' 2017, 'Basai-erdő' 2006. Tormafölde: 'Vétyemi-erdő' 1993. Páka-Dömefölde: 'Fejérlakosa-erdő' 2017. Zah: Zalaistvánd: 'Pácz-tető' 2017. Zalaszentgrót-Csáford: 'Piros-domb' 2000. Kallósd: 'Cserháti-erdő' 1994. Almásháza: 'Almásierdő' 1995. Ligetfalva: 'Almási-erdo’’ 1995. Dióskál: ‘Ungi-hegy' 2013. Zalamerenye: 'Kanicza-erdő' 2004. Nagykanizsa: 'Vajda' 2009 (F. S.), 'Alsó-erdő' 2009. Szepetnek: 'Csicsa-kunyhó' 2008 (H. T.). Tcs: Zalaszántó: 'Tátika' 2016. Khg: Rezi: 'Almás-domb' 2007, 'Kozma-tető', 'Hosszú-hegy' 2010, 'Szent-kút' 2016, 'Rezi-vár' 2007, 'Meleg-hegy' 2010, 'Bányafö-tető' 2011, 'Pörkölt-hegyek' 2011, 'Láz-tető' 2010, 'Kiscser-völgy' 2009, 'Keserü-torony-hegyek' 2009, 'Tüskés-hegyek' 2012, 'Fagyoskereszt' 1992. Vállus: 'Borjazó-domb', 'Égetett-tető', 'Rózsamező', 'Kétfahegyi-tető', 'Képestói-putri', 'Ivány-hát', 'Messzi-domb', 'Sáros-tó', 'Iván-hát', 'Abrincsos-völgy', 'Szent-Miklós-völgy', 'Láz-tető'. Keszthely: 'Kő-hát' 2016, 'Csókakő' 2010, 'Magyal-tető' 1999, 'Budai-hegy' 2002, 'Pilikári-erdő' 1992, 'Négyszögletü-hegy' 1992, 'Kis-Messzelátó' 2012, 'Nagy-Messzelátó’ 2011, 'Festetics-kilátó' 2011, 'Kübánya' 2009, 'Szár-hegy' 2007. Gyenesdiás: 'Kis- 
Messzelátó' 2017, 'Nagy-Messzelátó' 2006, 'Szík-tető' 2017, 'Pórag-hát' 2006, 'Meleg-hegy' 1997, 'Kö-mell' 1997, 'Varsás-hegy' 1995, 'Pipa-hegy', 'Nyilas-erdő' 2008, ‘Tüskéslap' 1995, 'Kesello’’ 1997, 'Öreg-Szék-tető' 1999, 'Ló-hegy’ 2006, ‘Pető-hegy' 1995, 'Meszes-hegy' 2015. Vonyarcvashegy: 'Vonyarci-fenyves' 1991, 'Vas-hegy' 2019, 'Vonyarci-cser' 2019, 'Hosszú-völgy' 2019, 'Malacos-tető’ 2019, 'Csalános-völgy' 2019. Balatongyörök: 'Csereze-hegy' 2019, 'Vashegyi-erdő' 2019, 'Padkő-erdő' 2006, 'Boncsos-tető’ 2014, 'Emberölö-völgy' 2006, 'Kerekhegy' 2005, 'Bodorhálás-tető' 2018, 'Pad-kő' 2015, 'Garga-hegy' 2008, 'Bece' 2005, 'Kígyós-völgy' 1995, 'Keserü-berek' 2014. Balatonederics: 'Sipos-torok' 2016, 'Edericsi-plató’ 2016.

\section{Platanthera bifolia (L.) Rich. 1. virens Tinant}

Mostly this form occurs in the Keszthely Mts.

KEF: 9066.3, 9067.3, 9068.3, 9069.4, 9165.4, 9165.3, 9166.3, 9166.4, 9167.1, 9167.2 , 9167.3, 9167.4, 9168.1, 9168.3, 9169.1, 9169.2, 9169.3, 9169.4, 9170.3, 9264.1, 9264.2, 9265.1, 9265.2, 9265.3, 9265.4, 9266.1, 9266.3, 9267.1, 9267.2, $9267.3,9269.2,9270.1,9365.1,9365.2,9365.3,9365.4,9366.3,9366.4,9367.3$, 9368.1, 9464.2, 9465.1, 9465.2, 9465.4, 9466.1, 9466.2, 9466.3, 9466.4, 9467.1, $9467.3,9467.4,9468.2,9468.3,9566.1,9566.2,9567.4,9568.1$.

\section{Platanthera chlorantha (Custer) Rchb.}

Habitat: tall-herb vegetation of ferns, alkaline fens, forest edges.

H: Zalaszombatfa: ‘Gálházi-rétek' 2010. Szijártóháza: ‘Tölgyfa-erdo”’ 1997 (†). G: Mumor: 'Csalános’ 1994. Pórszombat: 'Csikász-tó' 1996. Szilvágy: ‘Cseridülő' 2006, 'Határ-hegy' 1995, 'Felső-erdő’ 1995. Nova: 'Lőrincfa-mellék’ 1995, 'Makkosi-hegy' 2009.

KEF: 9265.4, 9266.3, 9364.2, 9364.4, 9365.4.

\section{Gymnadenia densiflora (Wahlenb.) A. Dietr.}

Habitat: forest edges, fallows, secondary Molinia meadows, steppes, orchards.

Kh: Gösfa: 'Gős-hegy' 2004 (BorbÁs (1887) G. conopsea adatának megerősítése). ELd: Kemendollár-Kemend: 'Kemendi-hegy' 2006. ZalaegerszegCsács: ‘Bozsoki-domb’ 1993. Muraszemenye-Aligvár: ‘Csányi-hegy’ 1995. Zah: Zalaszentgrót-Csáford: 'Som-tető', W slope of 'Bogos-domb’. Bezeréd-Zalakoppány: S slopes of 'Vergyálom'. Szentpéterúr: 'Nemesszer’. Dióskál: 'Szegfalu-hegy’, 'Felső-Pogányvár', 'Közép-hegyhát'. Zvh: Zalaszentgrót-Aranyod: 'Som-tető': 1996, 'Boggos-domb' 2005, Zalaszentgrót-Zalakoppány: 'Rátka-hegy' 1995. Bezeréd: 'Bezerédi-hegy' 2008. Szentpéterúr: 'Meleghegy-alja' 1995. Dióskál: 
'Öreg-hegy’ 2010, 'Kakas-hegy’ 2011, 'Közép-hegyhát' 1996. Zah: Zalaszentgrót: 'Pityer-domb' 1995, 'Bujtor-domb' 1995. Mh: Hollád: 'Szőlőhegy' (R. Gy.).

KEF: 9067.1, 9068.3, 9068.4, 9167.2, 9167.3, 9168.1, 9168.3, 9268.1, 9368.1, 9565.2.

\section{Gymnadenia conopsea (L.) R. Br.}

Habitat: Molinia meadows, alkaline fens, tall-herb vegetation of ferns, ditches.

AZv: Batyk: 'Zala-melléke’ 1993, 'Síki-rét' 2006. Zalaszentgrót-Tüskeszentpéter: 'Dombos-rét' 1993. Khg: Lesencefalu: in quarry $1991(\dagger)$. Lesenceistvánd: 'Csuhus-rét' 1991. Lesencetomaj: 'Serény' 1990, 'Homoki' 1990. Tm: Nemesvita: 'Felső-töreki láprét' 1992. Tapolca: ‘Viszló-mente’ - airport 1990.

Gymnadenia conopsea (L.) R. Br. 1. albiflora Zapal

AZv: Batyk: 'Zala-mellék' 2009.

KEF: 9060.1, 9070.1, 9170.2, 9170.3.

Gymnadenia odoratissima (L.) Rich.

Habitat: Molinia meadows.

Tm: Tapolca: 'Viszló-mente'.

KEF: 9070.1, 9170.2.

Gymnadenia $\times$ intermedia Peterm. (G. conopsea $\times$ G. odoratissima)

Habitat: Molinia meadows.

Tm: Lesenceistvánd: 'Sörény’ 1990. Tapolca: 'Viszló-mente' 1990.

KEF: 9070.1, 9170.2

\section{Dactylorbiza incarnata (L.) Soó}

Habitat: Molinia meadows, alkaline fens, tall-herb vegetation of ferns, ditches, tall-sedge vegetation, swamp forests, steppes, fallows, road verges.

FKh: Egervár: 'Kápolnai-domb’ 2013, ‘Kövecses-alja' 1991. Gösfa: ‘Feketeberek' 1992, ‘Telek-alja' 2009. FZv: Zalaegerszeg-Pózva: 'Nagy-rét' 1993, 'Pózvaitavak' 1991 (†), 'Tölles' 2005. H: Kerkateskánd: 'Hosszú-rét' 2007. G: Dobronhegy: 'Dabronyi-mező' 1998. Zalaegerszeg-Bazita: meadow of 'Pálosfai-patak' 2005. Kustányszeg: along 'Kislengyeli-patak' 2006, 'Basa-kútja' 1992. Milejszeg: 'Cserta-patak' 2006, 'Templom-oldal' 1995 (†). Becsvölgye-Pajzsszeg: 'Győrkapu-dűlo’’ 1992, 'Kis-kút' 2006. Barlahida: 'Nagy-rét' 2005, 'Kis-rét' 2002. Tófej: 
'Berekalja' 2009. Pusztaederics: 'Szompácsi-rét' 2009. Ortaháza: 'Alsó-rétek' 2008. Páka-Dömeháza: 'Lakosai-erdő' 2005. Kányavár: 'Alsó-rét' 2005. Lasztonya: 'Szentlőrinci-puszta' 2008, 'Pusztai-rétek' 2011. Bánokszentgyörgy: 'Pákaszeg' 2011, 'Telek-alja' 2006, 'Felső-hegy' 2006, 'Forrási-rét' 1990. Szentliszló: 'Uj-hegy alja' 1991. Bak: 'Gúla-berek' 1991 (†), 'Réti-földek-alja' (†), 'Válickairétek' 1990. Sárhida: 'Csöpögő' 1992. Bocfölde: 'Úrvölgy’ 2005, 'Bogárdi' 1991 (†). ELd: Zalaistvánd: 'Barkus-hegy' 1991, Nemesapáti: 'Kis-Újhegy’ 2008. Alsónemesapáti: 'Kertes' 1991, 'Bük-sürü' 1991. Zalaegerszeg-Csács: 'Bozsokidomb' 1994. Nagykapornak: 'Laki-hegy' 2011. Nemessándorháza: 'Szoboszlóiberek' 1993. Pölöske: 'Éva-sziget' 1996, 'Kis-mezö’ 1999 (†). Pusztaszentlászló: 'Falu-alja' 2005. Bucsuta: 'Peteházi-láprét' 2006. Börzönce: 'Felső-rétek' 2011. Oltárc: 'Nagy-rétek' 1990. Eszteregnye: 'Tószél-nádas' 1994. Zajk: 'Béci-patak' 1991. Prv: Nemesrádó: 'Mórházi-dủlő’ 1990 (†). Nemessándorháza: ‘Gombajirét' 1990, 'Sihaj' 2005. Zalaszentmihály: 'Sáros-berek' 2008, 'Nemesbebes' 2009. Pacsa: 'Felső-berek' 2013. Hahót: 'Szabados-berek' 2006, 'Zsibrik-berek' 1993. Gelse: 'Hosszúréti-dűlo’' 2014. Füzvölgy: 'Berki-rétek' 1995. Homokkomárom: 'Vadalmás-rét' 2012. Sormás-Nagykanizsa: 'Gördövény' 1994. Nagykanizsa: 'Osztott-rétek' 2014, 'Hidegkúti-legelő' 2012, 'Majkó-berek' 2012. NagykanizsaMiklósfa: 'Mórichelyi-halastavak' 1992. Zah: Zalaszentgrót-Aranyod: 'Csernak' 2015, 'Felső-hegy' 2011. Pakod: 'Borbás-hegy' 1997. Bezeréd: 'Bezerédi-szőlőhegy' 1995. Padár: 'Mádi-hegy' 2014. Dióskál: 'Ungi-hegy' 1996, 'Szegfalusihegy' 2009. Kerecseny: 'Fehér-hegy’ 2007, Orosztony: 'Pogácsa-völgy’ 2007, Csapi: 'Galamboki-vízfolyás' 2005. AZv: Batyk: 'Síki-rét' 2009, 'Zala-melléke' 1991. Zalaszentgrót-Tüskeszentpéter: 'Dombos-rét' 2009, 'Bitva' 2009. Zalaszentgrót-Aranyod: 'Csicseri-forrás' 1998. Zalaszentgrót-Csáford: 'Fölső-rét' 1998. Zalaszentlászló: 'Remic' 2008. Zalaszabar: 'Száraz-rétek' 2005. Zvh: Zalaszentgrót: 'Pityer-domb' 1996. Sénye: 'Határ-rét' 2005. Zalaszentlászló: 'Öreg-hegy' 1996, Karmacs: 'Vizes-rét' 1990. Hévíz: ‘Egregyi Ó-berek' 2000. Mm: Mihályfa: 'Fenyősi-patak' 1995. Tcs: Zalaszántó: 'Lapos-kúti-dülő' 1998. Várvölgy: 'Bándimezö’ 1991, 'Irtovány' 1990. Tm: Lesencefalu: in a quarry 1991 (†). Lesenceistvánd: 'Csuhus-rét' 1990. Lesencetomaj: 'Serény' 1991, 'Homoki' 1991. Nemesvita: 'Felső-töreki láprét' 1992. Tapolca: 'Viszló-mente' - airport 1989. Badacsonytördemic: 'Badacsonylábdi' railway station 1993. Kbm: Keszthely-Fenékpuszta: 'Balaton-part' 1990 (P. S.). Sármellék: 'Sármelléki-berek' 1991. Balatonszentgyörgy: 'Szentgyörgyi-legelő' 1993 (P. S.). Zalaszabar: 'Száraz-rétek' 2005. NybS: Zalakaros: 'Gástya' 2004, 'Bodoni-rét' 2004, 'Banyavölgyi-patak' 2004. Galambok: 'Vadszürü-dülo’’ 2004. Pat: 'Alsó-rétek' 2005.

KEF: 9067.1, 9067.4, 9068.1, 9068.3, 9068.4, 9069.1, 9166.4, 9167.1, 9167.2, $9167.3,9167.4,9168.1,9168.2,9169.2,9170.1,9170.3,9266.1,9266.2,9266.3$, 9267.1, 9267.2, 9267.3, 9267.4, 9269.2, 9269.3, 9269.4, 9366.2, 9366.3, 9366.4, 
9367.2, 9367.3, 9368.1, 9368.3, 9368.4, 9369.2, 9465.1, 9465.2, 9466.1, 9466.2, 9466.3, 9466.4, 9467.1, 9467.2, 9467.4, 9468.2, 9566 1, 9567.2, 9567.4, 9569.3.

Dactylorbiza incarnata (L.) Soó l. albida (Rchb. f.) Soó

Prv: Fűzvölgy: 'Berki-rétek' 1995. Kbm: Keszthely-Fenékpuszta: 'Balatonpart' 2003. Balatonszentgyörgy: at the shore of lake 'Balaton' 2005.

KEF: 9269.3, 9269.4, 9369.2, 9467.4.

Dactylorbiza incarnata (L.) Soó var. immaculata Romolini \& Sodi

G: Bak: ‘Válickai-rétek’ 1993 (†). Kbm: Sármellék: ‘Sármelléki-berek’ 1995 (†). KEF: 9267.1, 9269.3.

Dactylorbiza incarnata (L.) Soó f. ochrantha Landwehr

Azv:Batyk: 'Zala-melléke'.

KEF: 9068.1.

Dactylorbiza incarnata subsp. pulchella (Druce) Soó

Habitat: Molinia meadows, alkaline fens, tall-herb vegetation of ferns.

G: Ortaháza: 'Kétvízközi' 2008. ELd: Fűzvölgy: 'Berki-rétek' 1995. Prv: Gelse: 'Hosszúréti-dűlő’ 2014. Nagykanizsa-Miklósfa: 'Mórichelyi-halastavak' 1998.

KEF: $9366.3,9467.2,9467.4,9567.4$

Dactylorbiza incarnata subsp. hyphaematodes (Neumann) Landwehr

Habitat: Molinia meadows, tall-herb vegetation of ferns.

Prv: Nagykanizsa-Miklósfa: 'Mórichelyi-halastavak'.

Dactylorbiza incarnata subsp. ochroleuca (Wüstnei ex Boll) P. F. Hunt \& Summerh.

Habitat: Molinia meadows.

Azv: Batyk: 'Zala-melléke’ $1991(\dagger)$.

KEF: 9068.1.

Dactylorhiza viridis (L.) R. M. Bateman, Pridgeon \& M. W. Chase

Habitat: closed rocky grasslands, scrub forests, thermophilous oak (Quercus pubescens) forests. 
Khg: Gyenesdiás: 'Ló-hegy' 1993. Balatongyörök: 'Kerek-hegy’ 2007. Vállus: 'Csetényi-erdő' 1991 (P.S.) (†).

KEF: $9169.4,9270.1$.

\section{Dactylorbiza sambucina (L.) Soó}

Habitat: chestnut-oak forests.

Khg: Rezi: 'Kozma-tető'.

KEF: 9169.3.

\section{Dactylorbiza fuchsii (Druce) Soó}

Habitat: steppes, fallows, ditches, spruce plantations, tall-herb vegetation of ferns.

H: Zalaszombatfa: 'Nyakasháza' 2010 (B. O.). G: Lenti-Mumor: 'Csalános' 1991 (F. S.) (†). ELd: Zalaszentgrót-Csáford: 'Aszó-tető' 2008. KemendollárKemend: 'Kemendi-hegy' 2009. Kisbucsa: 'Szenttamási-major' 1995. Valkonya: 'spruce plantation in a garden' 2005 (MME ZHCS).

KEF: 9068.3, 9167.2, 9167.4, 9364.2, 9365.4, 9466.4.

\section{Dactylorbiza majalis (Rchb.) P. F. Hunt \& Summerh.}

Habitat: spring mires, tall-herb vegetation of ferns, mesotrophic wet meadows, swamp forests, fallows.

H: Magyarföld: 'Alsó-berek' 2008. Kh: Ozmánbük-Márkus: 'Márkus-telekalja' 2006. FZv: Zalalövő-Zalamindszent: 'Telek' 2009. G: Salomvár: 'Máriapart' 1991, 'Zeg-Bazita': along 'Pálosfai-patak' 2007. Dobronhegy: flushes within the village 1990. Becsvölgye-Kislengyel: 'Kócos-patak' 1992 (†), 'Győrkapudülő' 1992 (†). Csonkahegyhát: 'Gyögyvölgy’ 1992 (†). Szilvágy: ‘Medesi-patak' 1992. ELd: Kemend: 'Kemendi-hegy' 2000. Bucsuta: 'Peteházi-láprét' 2006. Tm: Lesenceistvánd: 'Csuhus-rét' 1991.

KEF: 9066.3, 9165.4, 9165.3, 9166.3, 9166.4, 9167.2, 9170.1, 9264.2, 9265.4, 9266.1, 9266.2, 9365.3.

\section{Dactylorhiza $\times$ aschersoniana (Hausskn.) Borsos \& Soó}

Habitat: tall-herb vegetation of ferns, mesotrophic wet meadows.

G: Zalaegerszeg-Bazita: 'Pálosfalvi-patak' 2007. Becsvölgye-Kislengyel: 'Győrkapu-dülő' 1992 (†). Tm: Lesenceistvánd: 'Csuhus-rét' 1991.

KEF: 9266.1, 9266.2, 9365.3. 
Neotinea ustulata (L.) R. M. Bateman, Pridgeon \& M. W. Chase subsp. ustulata

Habitat: lowland hay meadows, mesotrophic wet meadows, open rocky grasslands, orchards.

Kh: Vaspör-Velence: orchards within the village 2005. Zalaháshágy: 'Bakos-hegy' 2005. FZv: Zalalövő-Budafa: 'Kisház-alja' 1991 (†). Zalacséb: 'Román-hegy' 2005. H: Magyarszombatfa: 'Berki-hegy' 2008. Kerkafalva: 'Zsombékosi-dűlo’' 2008. Márokföld: along 'Szentgyörgyvölgyi-patak' 2012. Csesztreg: 'Felső-hernye’ 2008. G: Nova: 'Felső-hegy' 2009, 'Makkosi-hegy' 2004. Kustánszeg: 'Parasza' 2004. Becsvölgye-Pajzsszeg: ‘Gyepü-hegy’ 1990. Hottó-Zalaszentmihályfa: 'Szentmihály-hegy' 1991. Milejszeg: 'Lóka-hegy' 2000, 'Gesztenyés-hegy' 2007. Tm: Tapolca: 'Viszló-patak mente' - airport 1994. Khg: Cserszegtomaj: 'Gyötrős' 2007. Rezi: 'Kozma-tető' 2008. Vállus: 'Kétfahegyitető' 2009. Keszthely: 'Négyszögletü-hegy' 1995. Gyenesdiás: 'Kis-Messzelátó' 2006, 'Nagy-Messzelátó' 2006, 'Szík-tető' 2006, 'Pórag-hát' 2009, 'Tüskéslap' 1993, 'Kesellő' 1991. Vonyarcvashegy: 'Vonyarci-fenyves' 1991. Balatongyörök: 'Gula-tető' 2006.

KEF: 9165.2, 9166.3, 9166.4, 9169.3, 9169.4, 9170.1, 9170.2, 9264.1, 9264.2, 9264.4, 9265.2, 9265.3, 9265.4, 9266.1, 9266.3, 9269.2.

\section{Neotinea ustulata subsp. aestivalis (Kümpel) Kolnik, Vlčko \& Díté}

Habitat: steppes, forest edges with Molinia, fallows.

Kh: Gösfa: 'Vitárgya' 1992, 'Hétvezér-dombja' 1992. G: Gutorfölde: 'Baloghegy' 2004.

KEF: $9067.1,9366.4$.

Neotinea tridentata (Scop.) R. M. Bateman, Pridgeon \& M. W. Chase

Habitat: steppes, fallows, open rocky grasslands, scrub forests, orchards.

FKh: Egervár: 'Pince-domb' 1992. G: Keménfa: 'Köves-parti-erdő' 2017. Salomvár: 'Sóskás-part' 2009. Ms: Tornyiszentmiklós: 'Újfalui-hegy' 2001. ELd: Kemendollár: 'Kemendi-hegy' 2008. Vöckönd: 'Bagó-hegy' 2005. Zalaegerszeg-Csácsbozsok: 'Bozsoki-domb' 1995 (P. S.). Zalaegerszeg-Botfa: in cemetery 2004. Csatár: 'Határ-rét' 1997, 'Csöngető-hegy' 2012, 'Csöngető-völgy' 2012, 'Dári-domb' 2012, 'Kismező’ 2012. Kisbucsa: 'Kopasz-hegy’ 2005. Nemessándorháza: 'Szivácsi-dűlő’ 2013, ‘Szoboszlói-hegy’ 2012, ‘Öreg-hegy’ 2010, 'KisTörpön-hegy' 2010, 'Kü-hegy' 1998, 'Nagy-irtás' 1995. Nemesrádó: 'Kü-hegy' 2004. Páka-Dömefölde: ‘Gecsó-hegy’ 2004, 'Kányavári-hegy’ 1996. Szécsisziget: 'Szigeti-hegy' 2005. Muraszemenye: 'Csányi-hegy' 1996. Maróc: 'Maróci-hegy' 2004, in cemetery 2010, 'Temető-oldal' 2008, 'Hosszú-hegyhát' 2010, 'Laka- 
tos-part' 2010. Szentmargitfalva: 'Rózsa-hegy' 1996. Lispeszentadorján: 'Szentadorjáni-hegy' 2008, 'Hosszú-sürü’ 2005, 'Homok-lik' 2005, 'Lispei-hegy’ 2008, 'Ladányi-dűlo’' 2008. Bázakerettye: 'Bázai-hegy' 2011. Zah: Zalabér: 'Tekevölgy' 1991. Zalaszentgrót: 'Csernak' 2015, 'Felső-Aranyod' 2005. Zalaszentgrót-Csáford: 'Koppány-hegy’ 1996, ‘Bodokai-dűlő’ 1996, ‘Boggos-domb’ 1996, 'Látó-hegy' 2011, 'Szij-völgy' 2011. Bezeréd: 'Bezerédi-hegy' 1995, 'Kápolnailap' 1995. Zalaszentgrót-Zalakoppány: 'Rátka-hegy' 1995. Kallósd: 'Új-hegy' 1996. Padár: 'Csete-hegy' 1990. Dióskál: ‘Szegfalusi-hegy' 2009. Zvh: Zalaszentgrót: ‘Bujtor-domb’ 2008. Sénye: ‘Új-hegy’ 2007. Zalaköveskút: 'Kis-hegy’ 2005. Tcs: Lesenceistvánd: 'Kö-orra' 1993. Khg: Cserszegtomaj: ‘Gyötrös’ 2010. Keszthely: 'Négyszögletü-hegy' 1994. Gyenesdiás: 'Nagy-Messzelátó' 1993, 'Kő-mell' 1993, 'Pilikán' 1998, 'Pórag-hát' 2006, 'Tüskéslap' 1991, 'Kesellő' 1992. Lesenceistvánd: 'Kö-orra' 1995.

Neotinea tridentata (Scop.) R. M. Bateman, Pridgeon \& M. W. Chase 1. albiflora Waisb.

ELd: Zalaegerszeg-Botfa: ‘Rózsás’ 2015. Nemessándorháza: ‘Kü-hegy’ 1998. Zah: Zalabér: 'Teke-völgy' 1991.

KEF: 9067.3, 9068.1, 9068.3, 9068.4, 9165.4, 9166.1, 9167.2, 9167.3, 9167.4, $9168.1,9168.2,9168.3,9169.2,9169.3,9169.4,9170.1,9267.1,9267.2,9269.2$, 9368.1, 9465.2, 9465.3, 9465.4, 9466.1, 9466.3, 9466.4, 9565.2, 9566.1.

Neotinea $\times$ dietrichiana (Bogenh.) Kretzschmar, Eccarius \& H. Dietr. (N. ustulata $\times$ N. tridentata)

Habitat: open rocky grasslands.

Khg: Keszthely: 'Négyszögletü-hegy'. Gyenesdiás: 'Tüskéslap'.

KEF: $9169.4,9269.2$.

\section{Himantoglossum adriaticum $\mathrm{H}$. Baumann}

Habitat: scrub forests, thermophilous oak (Quercus pubescens) forests, road verges, ditches, open rocky grasslands, steppes, fallows, orchards.

Khg: Rezi: 'Rezi-vár' 1996, 'Kozma-tető' 2017. 'Fagyoskereszt' 1991 (P. S.). Vállus: 'Csetényi-erdő' 1991 (P. S.). Keszthely: 'Négyszögletü-hegy' 1995, 'Tüskés' 1995. Gyenesdiás: ‘Tüskés’ 2006. ELd: Kemend: 'Kemendi-hegy’ 2008. Pölöske: 'Öröm-hegy' 2001. Zah: Nagykapornak: 'Büki-hegy' 2016. Dióskál: 'Szegfaluihegy' 2009.

KEF: 9167.2, 9167.4, 9169.3, 9267.1, 9368.1. 
Anacamptis palustris (Jacq.) R. M. Bateman, Pridgeon \& M. W. Chase subsp.

\section{palustris}

Habitat: tall-sedge vegetation, alkaline fens, mesotrophic wet meadows, tall-herb vegetation of ferns.

AZv: Zalalövő: 'Kisház-alja' 1991. G: Zalaegerszeg-Bazita: along "Pálosfaipatak' 1991. Prv: Nemessándorháza: 'Sihaj' 2006. Zalaszentmihály: 'Nemes-Bebes' 2006. Füzvölgy: 'Berki-rétek' 2006. Sormás-Nagykanizsa: 'Gördövény' (H. T.) 2008. Nagykanizsa-Miklósfa: 'Mórichelyi-halastavak' 1990 (†). AZv: Batyk: 'Zala-mellék' 1991. Zalaszentgrót-Tüskeszentpéter: 'Dombos-rét' 1991, 'Csicseri-forrás' 1998. Zalaszentgrót-Csáford: 'Felső-rét' 2009. Zalaszentlászló: 'Remic' 2009. Zvh: Vindornyaszőlős: 'Vindornya-medence' in peat pit 1997. Karmacs: 'Vizes-rét' 1994. Sénye: 'Határ-rét' 2005. Tcs: Zalaszántó: 'Laposkúti-dűlo’' 2004. Tm: Lesencetomaj: 'Serény' 1990. Nemesvita: 'Felső-töreki' 1993. 1992. Kbm: Zalaszabar: 'Száraz-rétek' 2005. Keszthely-Fenékpuszta: 'Balaton-part' 2004. Balatonszentgyörgy: 'Szentgyörgyi-legelő' 2005. Sármellék: 'Sármelléki-berek' 1991. NybS: Zalakaros: 'Gástya' 2004, 'Bodoni-rét' 2004, along 'Banyavölgyi-patak' 2004.

KEF: 9068.1, 9068.3, 9165.1, 9168.3, 9169.2, 9269.1, 9269.2, 9269.3, 9170.1, $9170.3,9266.2,9267.2,9267.4,9269.1,9269.3,9269.4,9368.4,9369.2,9466.1$, $9466.2,9467.4,9468.2,9567.2,9567.4$.

Anacamptis palustris subsp. elegans (Heuff.) R. M. Bateman, Pridgeon \& M. W. Chase

Habitat: tall-sedge vegetation, alkaline fens, mesotrophic wet meadows, tall-herb vegetation of ferns.

H: Kerkateskánd: 'Hosszú-rét' 1998. Prv: Nemessándorháza: 'Sihaj' 2006. Zalaszentmihály: 'Nemes-Bebes' 2006. AZv: Batyk: 'Zala-mellék' 2009. Zalaszentgrót-Tüskeszentpéter: 'Dombos-rét' 2006, Zalaszentgrót-Csáford: 'Felsőrét' 2009. Zalaszentlászló: 'Laposkúti-dűlő' 2016, 'Remic' 2009. Kbm: Sármellék: in the meadow between railroads and 'Középső-kereszt-csatorna' 1991. Balatonszentgyörgy: 'Szentgyörgyi-legelö' 2005. Zalaszabar: 'Száraz-rétek' 2005. NybS: Zalakaros: 'Bodoni-rét' 2004.

KEF: 9068.1, 9068.3, 9168.2, 9267.2, 9267.4, 9269.3, 9269.4, 9367.2, 9369.2, 9368.4, 9369.2, 9465.1, 9465.2, 9468.2.

Anacamptis $\times$ timbali (Velen.) Kretzschmar, Eccarius \& H. Dietr. (A. palustris $\times$ A. coriphora)

Kbm: Balatonszentgyörgy: 'Szentgyörgyi-legelö' 1994, 2005, 2015. KEF: 9269.4, 9369.1. 


\section{Anacamptis pyramidalis (L.) Rich.}

Habitat: steppes, fallows, open rocky grasslands, road verges, forest edges, scrub forests, thermophilous oak (Quercus pubescens) forests, and orchards.

FKh:Gösfa: ‘Gös-hegy’1990.ELd:Kemend: 'Kemend-hegy’2008. Vöckönd: 'Belső-hegy’2007.Zalaegerszeg: 'Alsó-Mándi’2016. Nemessándorháza: 'Kő-hegy' 2005. Páka: 'Kányavári-hegy' 1996. Maróc: 'Maróci-hegy’ 2013. MuraszemenyeAligvár: 'Csányi-hegy' 2005. Zah: Dióskál: 'Ungi-hegy' 2009, 'Felső-Bogánvár' 2009. Khg: Cserszegtomaj: 'Gyötrös' 2007. Rezi: 'Pörkölt-hegyek' 2016, 'Várvölgyi-út' 1991. Vállus: 'Várvölgyi-út' 1991, 'Sáros-tó' 2012, 'Kétfahegyi-tető' 2009. Keszthely: 'Várvölgyi-út' 1991, 'Pilikári-erdö' 2009, 'Négyszögletü-hegy' 2004, 'Tüskés' 2004, 'Kübánya' 2016, 'Pilikáni-út' 1991. Gyenesdiás: 'Pilikán' 1997, 'Nagy-Messzelátó' 2016, 'Kis-Messzelátó' 2016, 'Pórag-hát' 2006, 'ÖregSzék-tető' 1997, 'Ló-hegy' 2006, 'Pajta-völgy' 1995, 'Nyilas-erdő', 'Kő-mell' 1992, 'Tüskéslap' 1997, 'Kesellő' 2004. Vonyarcvashegy: 'Büdöskúti-út' 2001, 'Csalános-völgy' 2012. Balatongyörök: 'Kígyós-völgy’ 2015. Tm: Lesencetomaj: 'Serény' 1995. Kbm: Balatonszentgyörgy: 'Szentgyörgyi-legelő' 2006.

Anacamptis pyramidalis (L.) Rich. f. albiflora Forsyth

Khg: 'Tüskés' 2005.

Anacamptis pyramidalis (L.) Rich. f. rubriflora Terrac.

FKh: Gösfa: ‘Gős-hegy' 1992.

KEF: 9067.1, 9167.2, 9169.2, 9169.4, 9170.1, 9267.2, 9269.2, 9269.4, 9368.1, 9369.2, 9465.2, 9466.1.

$\times$ Neotinacamptis durandii (Bréb.) B. Bock (Anacamptis pyramidalis $\times$ Neotinea ustulata)

Habitat: open rocky grasslands.

Khg: Keszthely: 'Négyszögü-hegy' 1996 (together with József Sulyok).

KEF: 9169.4.

Anacamptis morio (L.) R. M. Bateman, Pridgeon \& M. W. Chase

Habitat: lowland hay meadows, mesophilic hay meadows, alkaline fens, open rocky grasslands, scrub forests, orchards, and fallows.

FKh: Zalalövő: 'Borostyán-tó’ 2007. Ozmánbük: 'Kapa-hegy' 1990, 'Bozótirétek' 2005, 'Bozót-mellék' 2005, in cemetery 2005, 'Gelegenyés'. OzmánbükMárkus: 'Márkusi-telekalja' 2006, orchards at the houses 1998. Vaspör: 'Takács- 
domb' 2005, 'Ritás' 2005, in cemetery 2005. Vaspör-Velence: in sports court 2005, in cemetery 2005, in orchards and along ditches 2005, 'Német-hegy' 2005, 'Csatárihegy' 2005. Zalaháshágy: 'Csermegye’ 2005, 'Sibrik-kápolna' 2015, 'Bakos-hegy' 2005, 'Alsó-hegy' 2005. Zalacséb: 'Román-hegy’ 2005, 'Öreg-hegy' 2005, 'Csébhegy’ 2005, ‘Gesztenyés-hegy’ 2005. Hagyárosbőrönd: in orchard. Hagyáros: 'Hagyárosi-rétek' 2005, in cemetery 2005 (†). Bagod: 'Szentpáli-hegy' 1991, 'Kútvölgy' 1991, 'Szentpáli-kaszáló’ 2005. Zalaegerszeg-Hatház: airport 1991. Zalaboldogfa: 'Marton-hegy' 2006, 'Kövecses-hegy' 2006. Kiskutas: 'Szőlőhegy' 2006. Nagykutas: 'Szőlőhegy' 2009. Egervár: 'Csillag-hegy' 1990, 'Pince-domb’ 1991. Gösfa: ‘Gős-hegy' 1992. Zalaszentlőrinc: ‘Csöngeti-puszta' 1995. Zalaszentiván: 'Nagyfaludpuszta' 1995. FZv: Csöde: 'Zalamelléki-rétek' 2017, 'Malom-rét' 2016. Zalalövő: 'Alsó-berek' 2007, 'Mocsár' 2016, 'Kisház-alja' 1991. Salomvár: 'Cserta' 2005, 'Babos-rét' 1989 (P. S.) (†). Bagod: 'Martonfai-rét' (T. J.). Zalaegerszeg-Pózva: 'Nagy-rét' 1995. H: Csöde: in cemetery 2005. Magyarföld: 'Berki-hegy' 2008, 'Ferin-part' 2008, orchards at the houses 2008. Ramocsa: 'Bazsu' 1998, 'Szegaljairétek' 1998, in cemetery 2015. Kerkafalva: in cemetery 2015. Kerkakutas: orchards at the houses 2015, 'Kutasi-major' 2015, 'Nyározsd' 2015, 'Kozma-patak' 2015, in cemetery 2015. Felsőszenterzsébet: meadows along 'Kerka' 1998, 'Kertekaljaidülö' 1998. Alsószenterzsébet: 'Felső-rét' 2005, 'Lakos' 2005, in cemetery 2005, 'Kerka-rétek' 1998. Csesztreg-Kerkaújfalu: in cemetery 2005, 'Alsó-kertek' 2005, 'Meccő-sarok' 2005. Csesztreg: 'Mihomi-rét' 2014, 'Berek-mellék' 2015. Zalabaksa-Cup: orchards at the houses 1998, 'Cseri-rét' 2005, 'Turdi-rétek' 1998. Kerkabarabás: 'Monta-rét' 2014, 'Berek-rét' 2008, 'Tüskés' 2008, 'Puszta-rét' 2008. Szentgyörgyvölgy: 'Templom-domb' 1997, in the cemetery 2015, orchards at the houses 2012. Márokföld: orchards at the houses 2012, 'Kis-mező' 2012. Nemesnép: in the cemetery 2015. Lendvajakabfa: 'Egresi-rét' 2010. Resznek: 'Felső-berek' 2010, 'Nagy-rét' 2010, 'Holló-Cserta', sports court 2010, 'Cigányházi-rét' 2010, in the cemetery 2010. Baglad: 'Szállas' 2010, 'Alsógyöpi-dűlo’' 2010, orchards at the houses 2010. Szijártóháza: 'Tölgyfa-erdö' 1997, 'Bereg-rét'1993(†).Zalaszombatfa: 'Gálházi-rétek' 2010. Belsősárd: 'Házi-rétek' 2010. Lenti-Lentikápolna: in the cemetery 2003, 'Kápolnai-út' 2008. Lenti-Bárszentmihályfa: 'Füzesi-rét' - shooting range 2008, in the cemetery 2008, 'Saván-rét' 2008, 'Berek' 2008, orchards at the houses 2008. Lenti-Mumor: 'Felső-rét' 1998, 'Belső-rét' 1998, 'Kövecses' 2008. Lenti: 'Lenti-hegy' 1995. G: Zalalövő: 'Szűcs-házak' 2015, 'Irsapuszta' 1994. Keménfa: 'Keresztúr-puszta' 1995, 'Köles-irtás' 2017, 'Vizsi-dombja' 2009, in the cemetery 2004, 'Nagykövecses' 2017.Salomvár: ‘Gerga-völgy' 2004, 'Dózsa-hegy' 2004, 'Harkály-hegy' 2004, 'Sóskás-part' 2004, 'Szél-gyöp' 2004. Kávás: 'Zsimbahegy' 2004, 'Fűzkút' 2009, 'Öreghegy-alja' 2009. Boncodfölde: 'Puszta-part' 2009, 'Kéthegy-közt' 2009, 'Kis-hegy' 2004, 'Nagy-hegy' 1994. Kozmadombja: 'Tölles' 2015, orchards at the houses 2015, 'Dülők-alja' 2015, croft 2015, 'Temetői-dülö' 
2015. Kerkabarabás: 'Cserhegyi-szőlők' 2008. Kustánszeg: in the cemetery, 'Likidomb' - 'Szabó-hegy' 2016, orchards at the houses 2004. Kustánszeg-Parasza: orchards at the houses 2009, 'Konku' 2004. Csonkahegyhát: 'Gesztenye-hegy', 'Pöndör-hegy' 2006, 'Jámi-hegy' 2004, in the cemetery 2004, 'Gerencsér-lik' 2017, brick yard 1995, 'Gárosza' 2017, 'Kandikó’ 2019. Németfalu: 'Kis-hegy' 2004, 'Újhegy' 2006, 'Német-hegy' 2006, in the cemetery 2006, 'sports court' 2006, 'Babossürü' 2006, 'Egri-híd' 2006, 'Tótok-mezeje' 2004. Böde: 'Takói-dűlo’' 1992, 'Nagyvarjas' 2016, in the cemetery 2016. Hottó-Zalaszentmihályfa: 'Pergyászlói-hegy' 2004, 'Szentmihály-hegy' 1991. Dobronhegy: 'Szentmihály-hegy' 1991, 'Öreghegy' 2006, orchards at the houses 2006. Zalaegerszeg-Bazita: 'Zelefai-rétek' 2009, 'Jánka-hegy' 2005. Szilvágy: 'Alsó-rétek' 1992, 'Zátor' 2008, in the cemetery 2005, 'Nagy-hegy' 2008. Nova: 'Felső-hegy' 2005, 'Makkosi-hegy' 2004, 'Öreghegy' 2010, orchards at the houses 2005, 'Belső-bükk' 2005, 'Zágorhida' 1995. Barlahida: in the cemetery 2004, orchards at the houses 2004, 'Celena-völgye' 2004, 'Cserta-mente' 2005.Becsvölgye-Vargaszeg: 'Varga-hegy' 2016, 'Káposztáskert' 2004, 'Győrkapu-dülo’' 2004. Becsvölgye-Kislengyel: in the cemetery 1995, 'Nagy-rét' 2007. Becsvölgye-Pajzsszeg: orchard within the settlement 2000, 'Gyepü-hegy' 2009. Becsvölgye-Barabásszeg: 'Kardos-kert' 2004, 'Bánszeg' 2004. Becsvölgye-Kereseszeg 2007. Becsvölgye-Salomfa: 'Hosszi-rét' 2004. Milejszeg: 'György-völgy' 2016, 'Kis-hegy' 2004, 'Gesztenyés' 2016, 'Balázsfai-szőlőhegy' 1990, at the chapel 1990, 'Gesztenyés-hegy' 2004, 'Lóka-hegy' 2004, in the cemetery 2004, 'orchards at the houses' 2004, 'Zsidófa cemetery' - 'Tündérkert' 2017. Pálfiszeg: 'Pusztahegy' 2017, 'Konyhaszer' 2016, 'Avas' 2006, 'Cigány-árok' 2006, 'Bükönce' 2004, in the cemetery 2004. Nagylengyel: 'Új-hegy' 2010. Gombosszeg: orchards at the houses 2016. Ormándlak: 'Laki-hegy' 2008. Gellénháza: 'Budaihegy' 2012, 'Szőlőhegy-púp' 2016. Hernyék: in the cemetery 1996. Zalatárnok: 'Szentgyörgy-hegy' 2008, in the cemetery 2007. Zalatárnok-Vakola: in the cemetery 2016. Mikekarácsonyfa: in the cemetery 2011. Gutorfölde-Rádiháza: 'Mézeshegyi kereszt' 2007. Pusztaederics: 'Belső-hegy' 2007, 'Új-hegy' 2007. Pusztamagyaród: 'Külső-hegy' 2006. Petrikeresztúr: 'Keresztúri-hegy' 2008, 'Pató-hegy' 2008. ELd: Zalaistvánd: in the cemetery 1991, orchards at the houses 1991. Kemendollár: 'Kemendi-hegy' 1995, 'Almás-dülö' 2011. Vöckönd: 'Cingér-föld' 1990. Petőhenye: 'Köszörüs' 2011, 'Csillag-hegy' 1995, 'Alsó-erdő' 2004, 'Avasdűlo’' 1990. Nemesapáti: 'Compó-rét' 2017, 'Csertó-hegy’ 1998. Alsónemesapáti: 'Avas-hegy' 1992, 'Nagy-Újhegy' 1995. Orbányosfa: 'Felső-rét' 2005, 'Szentegyházilegelo’' 2005, 'Hegyaljai-dűlő' 2005, 'Bánhegyi-dőlő' 2005 (†). Zalaegerszeg: 'Mándi-domb' 1994. Kisbucsa: 'Szarka-hegy' 1992, 'Hosszú-hegy' 2011, 'Kopasz-hegy' 2005, in the cemetery 2011. Nagykapornak: 'Laki-hegy' 2008, 'Váras-hegy' 1994. Nemeshetés: 'Öreg-hegy' 2004, 'Gesztenyés' 2004, 'Kucogi-hegy' 2004. Nemessándorháza: 'Szoboszlói-hegy' 1994, 'Kis-Törpön-hegy' 1994, 'Kü-hegy' 1993, 
'Nagyirtás' 2004. Misefa: 'Belső-hegy’ 1996. Csatár: ‘Csatári-hegy’2010, 'Kincsemhegy' 1991, 'Dári-domb' 2011, 'Kismező' 2011, 'Csöngető-völgy’ 2011, ‘Örömhegy' 2005, in the cemetery 2010. Pölöske: 'Öröm-hegy’ 2005, ‘Öreg-hegy’ 2006. Zalaszentmihály: 'Koldus-hegy' 1993. Söjtör: 'Gene-hegy’ 1996. Hahót: 'Páncsik' 2003, 'Belső-hegy' 2004. Páka-Dömefölde: ‘Csörgei-dűlő' 2004, 'Dömeföldi-hegy' 1996, 'Kányavári-hegy' 1994. Maróc: 'Temetői-oldal' 2004, 'Hosszú-hegyhát' 2004, 'Bertalan-oldal' 2010. Lasztonya: 'Kis-hegy' 2011. Szentmargitfalva: 'Öreghegy' 1996, 'Justin-hegy' 1995. Lispeszentadorján: 'Homok-lik' 2005, 2010, 'Pázsit' 2005, 'Lapányi-dülő' 2010. Bázakerettye-Kerettye: orchards at the houses, sports court 2005 (B. Á.). Bázakerettye-Báza: 'Kisbüki-dűlo’’ 2011, 'Homoki-dülő' 2011. Bánokszentgyörgy: 'Páka-szeg' 2011. Oltárc: 'Delelő' 1993. Eszteregnye: ‘Ördöngős-völgy' 2008, in the cemetery 2004. Muraszemenye: ‘Csányi-hegy’ 1995. Becsehely: 'Bika-rét' 2004. Prv: Orbányosfa: 'Felső-rét' 2005. Kilimán: 'Backói-mező' 2008. Sormás-Nagykanizsa: 'Gördövény’ 1995, 'Lőtér' 2005. Nagykanizsa-Miklósfa: 'Szorgalom-rét' 2009, 'Mórichelyi-tavak' 1990 (†), along ‘Surdi-patak' 2000. Zah: Zalabér: 'Teke-völgy' 1990. Zalaszentgrót-Csáford: 'Som-tető' 2006, 'Bogos-domb’ 1994. Gyürűs: ‘Öreg-hegy' 1994. Kehidakustány-Barátsziget: 'Paperdő’ 1994, 'Öreg-hegy' 1994, 'Csoma-tető' 2005. Nagykapornak: 'Hársasaljaidűlő’ 2008. Almásháza: 'Fábián-hegy’ 2011. Tilaj: 'Zombor-hegy' 2012. Nemesrádó: 'Rádi-hegy' 1996. Dióskál: 'Ingi-hegy' 2005. Kerecseny: 'Alsó-Sáncos-rét' 2006, 'Fehér-hegy' 2002, 'Bagácsa-völgy' 2008. Orosztony: 'Pogácsa-völgy' 2008. Zalamerenye: 'Vadász-lénia' 2004. Nagybakónak: 'Pakarics-hegy' 2010. Nagykanizsa-Miklósfa: 'Mórichelyi-bükk' 2008. Liszó: 'Hosszúsűrű-mező' 2008. Surd: 'Malom-felső-rét' 2012, 'Nagy-rét' 2012, 'Bucsai-hegy' 2012, 'Szakály-hegy’ 2012. Somogybükkösd: 'Öreg-hegy' 2012, 'Kismező' 2012. AZv: Batyk: 'Zala-mellék' 1992 (P. S.). Zvh: Zalaszentgrót: 'Huszonya' 2002. Mm: Óhíd-Mihályfa: along 'Fenyősi-patak' 1994. PDh: Kisvásárhely: ‘Fás-legelő' 1994. Tcs: Nagygörbő: ‘Kovácsi-hegy' 2012. Vindornyaszőlős: ‘Öreg-hegy' 2012. Zalaszántó: 'Vatka' 2009, 'Lapos-kúti-dülö’ 1992. Várvölgy: 'Zsidi-legelö’ 1992, 'Bándi-mező' 1990. Khg: Cserszegtomaj: ‘Gyötrös’ 2012. Keszthely-Vállus: 'Várvölgyi-út' 1993. Gyenesdiás: ‘Tüskéslap’ 1993, 'Kesello’’ 1991. Vonyarcvashegy: 'Vonyarci-fenyves' 1991. Lesenceistvánd: 'Berkenyés-dűlő' 2015. Tm: Tapolca: 'Viszló-mente' - airport 1989. Kbm: Keszthely-Fenékpuszta: 'Balaton-part' 1990. Balatonszentgyörgy: 'Szentgyörgyi-legelo’’ 2001. NybS: Zalakaros: along ‘Banya-völgyi-patak’ 2004.

\section{Anacamptis morio var. valida Verm.}

H: Márokföld: orchards at the houses 2012, 'Kis-mező’ 2012. ELd: Páka-Dömefölde: ‘Csörgei-dűlo’’ 2004. Nemessándorháza: 'Nagyirtás’ 2004. Khg: Keszthely-Vállus: 'Várvölgyi-út' 1993. 


\section{Anacamptis morio f. albiflora E. G. Camus}

FKh: Zalalövő: 'Borostyántó' 2007. Zalacséb: 'Román-hegy' 2005, 'Öreghegy' 2005. H: Csöde: in the cemetery 2005. Lendvajakabfa: 'Egresi-rét' 2010. G: Keménfa: 'Keresztúr-puszta' 1995. Boncodfölde: 'Puszta-part' 2009. KustánszegParasza: orchards at the houses 2009. Hottó-Zalaszentmihályfa: 'Pergyászlóihegy' 2004, 'Szentmihály-hegy' 1991. Zalaegerszeg-Bazita: 'Zelefai-rétek' 2009, 'Jánka-hegy' 2005. Csonkahegyhát: 'Pöndör-hegy' 2006. Pálfiszeg: 'Pusztahegy' 2017. ELd: Nemeshetés: ‘Öreg-hegy’ 2004. Csatár: 'Csatári-hegy' 2010. Zalaszentmihály: 'Koldus-hegy' 1993. Zah: Kehidakustány-Barátsziget: 'Pap-erdő' 1994, 'Öreg-hegy' 1994. Nagykapornak: 'Hársasaljai-dűlol' 2008. Khg: Keszthely-Vállus: 'Várvölgyi-út' 1995.

KEF: 9065.4, 9066.3, 9066.4, 9067.1, 9067.2, 9067.3, 9067.4, 9068.1, 9068.3, 9068.4, 9069.1, 9069.3, 9070.1, 9070.2, 9165.1, 9165.2, 9165.3, 9165.4, 9166.1, $9166.2,9166.3,9166.4,9167.1,9167.2,9167.3,9167.4,9168.1,9168.3,9168.4$, 9169.1, 9169.2, 9169.4, 9170.1, 9170.2, 9264.1, 9264.2, 9264.4, 9265.1, 9265.3, 9265.4, 9266.1, 9266.2, 9266.3, 9266.4, 9267.1, 9267.2, 9368.1, 9269.2, 9269.3, 9269.4, 9270.1, 9364.2, 9364.4, 9365.1, 9365.2, 9365.3, 9365.4, 9366.1, 9366.4, 9367.1, 9367.3, 9367.4, 9368.1, 9368.3, 9369.2, 9465.2, 9465.4, 9466.1, 9466.3, 9466.4, 9467.3, 9467.4, 9468.1, 9468.2, 9565.3, 9566.1, 9566.3, 9567.1, 9567.2, 9567.4, 9568.3, 9667.2, 9667.3, 9667.4.

Anacamptis coriophora (L.) R. M. Bateman, Pridgeon \& M. W. Chase

Habitat: alkaline fens.

AZv: Batyk: Zala-mellék (P. S.), 1989, last flowered in 1995. Tm: Tapolca: Viszló-patak mente 1988. Kbm: Keszthely-Fenékpuszta: Balaton-part 1988. Balatonszentgyörgy: 'Szentgyörgyi-legelö' 2005.

Anacamptis coriophora f. luteo-viridis D. Rös \& R. Rös.

Balatonszentgyörgy: 'Szentgyörgyi-legelö' 2005.

KEF: 9369.2, 9369.3, 9369.4, 9767.1, 9767.2, 9768.1.

\section{Ophrys insectifera L.}

Habitat: scrub forests, open rocky grasslands, black pine plantations.

Khg: Rezi: ‘Bányafö-tető' 1992, ‘Pörkölt-hegyek' 1992. Vállus: 'Kétfahegyitető' 2004. Keszthely: 'Tömlöc-hegy' 1998, 'Sátor magasa' 1993, 'Négyszögletűhegy’ 1993, 'Pénzes-gödrök' 1993, 'Kübánya' 1995 (A. L.). Gyenesdiás: 'NagyMesszelátó' 2004, 'Kis-Messzelátó' 2004, 'Pórag-hát' 2006, ‘Tüskéslap' 1995, ‘Kő- 
mell' 1993, 'Lakatos-hegy' 1991, 'Nyilas-erdő' 2004, 'Tüskéslap' 2006, 'Vadlánybarlang' 1997.

\section{Ophrys insectifera f. luteomarginata Lewis}

Habitat: scrubs and rocky grasslands.

Khg: Gyenesdiás: 'Lakatos-hegy' 1995.

KEF: $9169.2,9169.4,9269.2,9270.1$.

\section{Ophrys apifera Hudson}

Habitat: steppes, open and closed rocky grasslands, alkaline fens, fallows, road verges, orchards.

FKh: Gösfa: 'Vitárgya' 2014. Vasboldogasszony: 'Kakas-szőlő' 1995. Egervár: 'Kápolna-domb' 2014. AZv: Batyk: 'Zala-mellék' 2004. ELd: Kemend: 'Kemendihegy' 1994, 'Csertói-dűlő' 1995. Vöckönd: 'Bagó-hegy’ 1996. Nemesapáti: ‘KisÚjhegy' 1995, ‘Templom-domb' 1996, 'Compó-rét' 1996. Alsónemesapáti: 'Büksürü' 1996, 'Nagy-Újhegy' 1995. Zalaegerszeg: ‘Bozsoki-domb’ 1995, main road nr 762005 (†). Nagykapornak: 'Laki-hegy' 2008. Csatár: 'Kismező'. Misefa: 'Misefaihegy' 1999. Pölöske: ‘Öröm-hegy' 2011, 'Kis-hegy' 1995. Nemessándorháza: 'Kő-hegy'. Zalaszentmihály: 'Koldus-hegy' 1995. Maróc: 'Maróci-hegy' 2014. Lispeszentadorján: 'Szentadorjáni-hegy' 2014. Kiscsehi: 'Tekincs-hegy' 2008 (L. A.). Bázakerettye: in the park of the swimming pool 2015 (B. Á.). Prv: Füzvölgy: 'Berki-rétek'. Zah: Zalabér: 'Kápolnai-oldal' 2008, 'Teke-völgy' 2016 (V. J.). Zalaszentgrót-Aranyod: 'Csernak' 2008, 'Aszó-tető' 2008, 'Kerék-mező' 2008. Zalaszentgrót-Csáford: 'Som-tető' 1995, 'Varga-domb' 1995. Gyűrűs: 'Öreg-hegy' 2002. Bezeréd: 'Bezerédi-hegy' 1995. Zalaszentgrót-Zalakoppány: 'Rátka-hegy' 2008. Padár: 'Mádi-hegy' 1995, 'Csete-hegy' 2014. Nemesrádó: 'Rádi-hegy' 1995. Tilaj: 'Zombor-hegy' 1995. Szentpéterúr-Nemesszer: 'Jancsika' 1995, 'Meleg-hegyalja' 1995. Dióskál: 'Ungi-hegy' 2009, 'Pogányvár' 2009, 'Közép-hegyhát' 2010. Zvh: Zalaköveskút: 'Kis-hegy' 1996. Khg: Keszthely: 'Pilikán’ 1996 (A. L.). Gyenesdiás: 'Kőmell’ 1991 (P. S.). Balatongyörök: meadow at 'Római-forrás' 1996 (A. L.). Zalaszántó: 'Lapos-kúti-dűlő' (MME ZHCS). Mh: Hollád: 'Szőlőhegy' 2015 (R. Gy.).

Ophrys apifera var. aurita (Moggridge) Gremli - FKh: Gösfa: 'Vitárgya' 2014. Egervár: 'Kápolna-domb' 2014. ELd: Kemend: 'Kemendi-hegy' 1995. Nemesapáti: 'Kis-Újhegy' 1995. Zalaszentmihály: 'Koldus-hegy' 1995. Maróc: 'Maróci-hegy' 2014. Lispeszentadorján: 'Szentadorjáni-hegy' 2014. Zah: Zalabér: 'Kápolnai-oldal' 2008. Zalaszentgrót-Aranyod: 'Csernak' 2008, 'Aszó-tető' 2008. Bezeréd: ‘Bezerédi-hegy’ 1995. Zalaszentgrót-Zalakoppány: 'Rátka-hegy’ 2008. 
Nemesrádó: 'Rádi-hegy' 1995. Dióskál: 'Közép-hegyhát' 2010. Mh: Hollád: 'Szőlőhegy’ 2015 (R. Gy.).

Ophrys apifera var. flavescens Rosbach - Zah: Zalaszentgrót-Aranyod: 'Csernak' 2008.

Ophrys apifera var. fulvofusca M. P. Grasso \& Scrugli - Eld: Nemesapáti: 'Kis-Újhegy' 1995. Alsónemesapáti: 'Bük-sürü' 1995.

Ophrys apifera var. chlorantha (Hegetschweiler) K. Richter - Eld: Misefa: 'Zsíros-hegy' 1998. Zalaegerszeg: 'Bozsoki-domb' 2019.

Ophrys apifera var. bicolor (O. Naegeli) E. Nelson - Eld: Misefa: 'Zsíroshegy' 1998.

Ophrys apifera var. friburgensis Freyhold - Eld: Alsónemesapáti: 'Bük-sürü' 1995. Nemesrádó: 'Rádi-hegy' 1995.

Ophrys apifera var. botteronii (Chodat) Aschers. \& Graebner - Zah: Nemesrádó: 'Rádi-hegy'.

Ophrys apifera var. trollii (Hegetschweiler) Reich. fil. - Zah: Nemesrádó: 'Rádi-hegy' 1995.

Ophrys apifera var. curviflora A. Soulie - ELd: Alsónemesapáti: 'Bük-sűrü' 2000, 'Nagy-Újhegy' 2000. Zah: Nemesrádó: 'Rádi-hegy' 1995.

KEF: 9067.1, 9067.3, 9068.1, 9068.3, 9167.2, 9167.3, 9167.4, 9168.1, 9168.2, $9168.3,9169.2,9267.1,9267.2,9268.1,9269.2,9270.1,9368.1,9465.2,9466.1$, 9466.3, 9467.4.

\section{Ophrys sphegodes Mill.}

Habitat: steppes, open rocky grasslands, alkaline fens, orchards, chestnut plantations.

ELd: Zalaistvánd: 'Barkus-hegy' 2008. Kemendollár: 'Kemendi-hegy' 1994. Vöckönd: 'Bagó-hegy' 1998. Alsónemesapáti: 'Belső-hegy' 1995, 'Nagy-Újhegy' 1999. Kisbucsa: 'Hosszú-hegy' 2006. Nemessándorháza: 'Szoboszlói-hegy’ 1994. Csatár: 'Dári-domb' 2011, 'Kismező' 2011. Zalaszentmihály: 'Koldus-hegy' 1995, 'Bebesi-hegy' 1995. Hahót: 'Belső-hegy' 2001. Páka-Dömefölde: 'Gecsó-hegy' 2002, 'Kányavári-hegy' 1996. Szentmargitfalva: 'Rózsa-hegy' 1996. Muraszemenye: 'Csányi-hegy' 1995. Zah: Zalaszentgrót-Csáford: 'Varga-domb' 1996. Gyürüs: 'Öreg-hegy' 1995. Kallósd: 'Új-hegy' 1996, 'Öreg-hegy’ 2008. Kehidakustány-Barátsziget: 'Csoma-tető’ 2002, 'Öreg-hegy’ 1996. Nemesrádó: 'Rádihegy’ 1995. Dióskál: 'Káli-hegy' 2013. Nagybakónak: 'Pakarics-hegy’ 2010. Zvh: Zalaszentgrót: 'Huszonya' 2006, 'Szent Anna kápolna' 2008. KehidakustányKustány: 'Papucshegy' 1996, 'Kis-hegy' 1996. Zalaköveskút: 'Kis-hegy' 1996, 'Gesztenye-hegy' 1996. Karmacs: 'Vizes-rét' 1999. Tcs: Nagygörbő: 'Szőlőhegy' 2012. Tapolca: 'Viszló-mente' - airport 1989. Kbm: Keszthely-Fenékpuszta: 
'Balaton-part' 1999 (MME ZHCS). Balatonszentgyörgy: 'Szentgyörgyi-legelö' 1999 (P. S.). Balatonmagyaród: 'Hídvégpuszta' 2018 (T. M.).

KEF: 9067.2, 9067.4, 9068.3, 9068.4, 9069.3, 9167.2, 9167.3, 9167.4, 9168.1, $9168.2,9170.1,9170.2,9267.1,9267.2,9269.3,9269.4,9367.3,9368.1,9369.2$, 9369.3, 9465.2, 9466.1, 9468.1, 9565.2.

\section{Opbrys fuciflora (F. W. Schmidt) Moench}

Habitat: steppes.

Eld: region of Letenye 2001, region of Zalaszentgrót 2013 (K. B.). KEF: 9068, 9466.

\section{Habitat preference of the studied taxa}

All three species of the Cephalanthera genus are present in natural forests. Cephalanthera rubra occurs in the calcareous Eastern Zala Hills and in the dolomite block, predominantly in beech forests with poor species composition. The area of Cephalanthera damasonium is similar, while it also grows in oak forests. Cephalanthera longifolia has a wider ecological tolerance; it is found throughout the area, alongside the forests, also in anthropogenically influenced sites, and orchards.

Neottia nidus-avis, the most common orchid in forests, occurs in the whole area, such as $N$. ovata, but the latter is often associated with extensive orchards, especially chestnut plantations.

The largest genus of the research area is Epipactis. Of the previously known 'conventional' species, Epipactis palustris is still scattered in wetland habitats. Epipactis microphylla can be found in forests of the Egerszeg-Letenye Hills, Zalaapáti Ridge, and the Keszthely Mts, but also present in semi-natural grasslands of settlements. Today, Epipactis atrorubens is predominantly found in xerotherm oak forests and bush forests on dolomite bedrock, while its previously known occurrence data are amended by some of its remnant subpopulations at four sites in forests of loess hills. Epipactis purpurata is located in the middlewestern part of the research area, where it is abundant in beech forests, Illyrian hornbeam and oak forests, and in pine forests. Occasionally, the natural hybrid of Epipactis purpurata and Epipactis helleborine (Epipactis $\times$ schulze) is also present. Epipactis muelleri is one of the rare species, and besides the Keszthely Mts, it has recently colonized on the secondary steppes of loess hills under Pinus sylvestris. Epipactis leptochila occurs in the Illyrian beech forests of calcareous hills, and in forests with dolomite bedrock. The type species of the Epipactis helleborine group is common, found in most of the microregions; besides the zonal forests, it is also present in the planted pine forests and urban parks. Among the new subspecies 
described recently, Epipactis helleborine subsp. minor was also found, sometimes in significant populations (Göcsej, Szentpéterfölde Forest, Oltárc Forest). Several late-blooming populations can be identified as the unresolved taxon, Epipactis helleborine subsp. moratoria. Epipactis helleborine subsp. latina is new to the country, which only lives on the dolomites of the Keszthely Mts. It is a thermophilous plant, which only lives in the xerotherm oak forests, and on the southern sides of bush forests; in the latter habitat, it grows in the rings of Cotinus coggygria, which typically surround scattered trees of Fraxinus ornus and Quercus pubescens. It blooms only in case of proper humidity of the habitat; lacking the adequate amount of seasonal precipitation, this species might be dormant for years. Epipactis helleborine subsp. leutei, which is also a new species for the country, is known from the Keszthely Mts. Its suitable habitats are shady and deep valleys with beech and hornbeam forests. Epipactis peitzii s. 1. (Somlyay) has also been found in the area, which also lives in the dolomite blocks with 'nudum' undergrowth, and its blooming also depends on the precipitation conditions of the given year. Further investigation is needed to resolve the relationship between Epipactis peitzii and E. komoricensis, which were described in Slovakia. Based on the research by Gábor Sramkó, the plants of the locus classicus in Germany, and the populations of the Keszthely Mts and the surrounding areas are genetically separated (Sramkó ex verb.). In the surrounding area of Keszthely, the unspecified hybrid of Epipactis peitzii s. 1. and E. helleborine s. 1. was also observed. The species, Epipactis tallosii, E. pontica, and E. nordeniorum are found everywhere west of the lower Zala Valley. Their standard habitat requirements are hornbeam and oak, and beech forests, while E. nordeniorum often appears in 'nudum' pine forests. In South Zala, the hybrids of the three species appear in the Illyrian beech forests, and it would be important to determine their relationship by phylogenetic surveys. In contrast to the three previous species, Epipactis voethii was rarely ( 5 sites) found on loess hills, but it is more often present in dolomite oak and beech forests, and in road verges. These habitats also include a natural hybrid with Epipactis helleborine, E. $\times$ kezlinekii. The locally rarest species of the genus is Epipactis moravica, which is found only in 2 locations in the area of Hollád, in atypical habitats (young hornbeam forest and a forest clearing), largely different from the wet sites where the plant is abundant elsewhere. The exact taxonomic classification of plants in the Epipactis neglecta agg. is problematic, with some populations showing a transition between Epipactis neglecta and E. naousaensis from Greece. The difference also shows up in the flowering period, as a group of Epipactis neglecta in the middle of loess hills blooms in July, while a group of morphologically different, mostly distinct individuals starts blooming at the beginning of August. 
The historical data of Limodorum abortivum has not been confirmed recently, its present occurrences are limited to the xerotherm oak and scrub forests of the southwestern slopes of the dolomite blocks in the Keszthely Mts. This is the only orchid that extends in large numbers to old Pinus nigra forests, which are planted in large numbers on dolomite bedrock here.

Spiranthes spiralis blooms at the end of the summer, and the beginning of autumn: the centre of the distribution of the species is located in the eastern part of the area. It is abundant on acidic soil in dwelling areas, vineyards, orchards, and cemeteries, where acidofrequent meadows are dominated by Festuca rubra.

The Orchis genus is represented by four taxa and a hybrid in Zala County; each grows on calcareous soils. Orchis militaris and $O$. purpurea are present in large numbers of individuals. The former is mainly found in marshlands, and sunny steppes of hills, the latter is common among the steppes and the fallows, or in various deciduous forests. Where the two parent species coexist, their natural hybrid, called Orchis $\times$ bybrida is also often present. Orchis mascula subsp. signifera is known only in one location in the Keszthely Mts, from an old chestnut plantation of the basalt bedrock region of the mountain. The population was found based on a herbarium sheet collected 40 years ago (Gotthárd 1976). The occurrence of Orchis pallens near Vállus has also been confirmed, with a small, endangered population (Bauer ex verb.).

Platanthera bifolia is widespread and often found in natural forests, while it is predominantly featured by marshes, hornbeam and oak forests, and beech forests along the marshes of Kerka. Platanthera chlorantha, however, is found only in forests, forest edges, and forests of Göcsej and Hetés.

Changes in the occurrences of the genus Gymnadenia are remarkable of the area. The only population with approximately a dozen individuals of Gymnadenia odoratissima can be found on one of the meadows of the Tapolca Basin. In this site, Gymnadenia conopsea has been discovered at several locations, otherwise, it only occurs in marshes along the Zala River. The third member of the genus, Gymnadenia densiflora, was discovered during a thematic research. This species has been conserved in only few herbarium sheets from the country, with sites that can be found without exception around the capital of the country (Szépligeti 1875, Filarszky 1889, Poland 1894 and Simonkai 1904, published in Molnár et al. 2012). The species is defined as a wet meadow species (DELFORge 2005, HÁJEK et al. 2005), but in this case, its habitats are always vineyards and secondary steppes dominated by Brachypodium pinnatum. In the country, only these occurrences in the Zala Hills have been known of the species, although recently it has also been reported in a similar site of the Marcal Ridge (Rozner ex verb. in 2015). 
The Dactylorbiza genus is represented by several species here. The most common species is Dactylorbiza incarnata, which grows on different meadows and marshes; while two subspecies (subsp. pulchella and subsp. hyphaematodes) were also found, as well as several interesting colour variations. The famous population of Dactylorbiza incarnata subsp. ochroleuca of the Batyki marsh was found only once on the side of the railway embankment on 6 June, 1991; since then, it has not been found there. Dactylorhiza majalis is a plant of cooler, nutrient-poor habitats in the western areas, known in the east in the Lesence bog and in occasional settlements in northern Zala. Dactylorhiza fuchsii is a mountain species, accordingly, no constant population of the low colline landscape is known. In the past, the plant was found six times, mostly with one or two individuals that lived for 1-5 years. While its former locations were found in the forest edges and road verges of the Göcsej and Heti forests, its last known sites were on the steppes of the Eastern Zala Hills. The occurrences of Dactylorbiza viridis and D. sambucina in the Keszthely Mts certainly preserve the memory of a much cooler climate. The number of known populations of both species has significantly declined, probably due to global warming, and the lack of appropriate precipitation.

Two species of the genus Neotinea are known in the area. Due to its habitat preference, Neotinea ustulata lives in two distinct habitats with different vegetation and climatic environment; in the west, it grows on the rainy mountainous meadows, marshes, river valleys, vineyards, and orchards of the acidic soils of Hetés, Göcsej, and Upper Kemeneshát, while in the east, the dolomite cliffs of the Keszthely Mts and the marshes of the Tapolca Basin harbour the species. Surprisingly, I could not find the species on the steppes of vineyards that represent the habitat of many other orchid species. Neotinea ustulata subsp. aestivalis is phenologically distinct from the type species with its blooming at the end of June and with its higher, more robust appearance. It is extremely vulnerable at both locations. The xerotherm-mesophilic meadows of the Eastern Zala Hills are suitable habitats for Neotinea tridentata. It is an ecosystem health indicator species, which is always found in natural grasslands, never in the disturbed or destroyed parts of the site; while it colonizes the fallows only as succession progresses, after the colonization of Brachypodium pinnatum, and Bromus erectus. In the eastern part of the area, it lives in the rocky grasslands of dolomite hills; these sites also harbour the natural hybrid of $N$. tridentata and $N$. ustulata ( $N . \times$ dietrichiana). Moreover, Neotinacamptis durandii, a spontaneous hybrid with Anacamptis pyramidalis was also found near Keszthely.

Himantoglossum adriaticum was previously known in the Keszthely Mts, where new locations of the species were registered, while four localities in the Eastern Zala Hills were also found. 
The genus Anacamptis is represented by five species and two hybrids in the area. Anacamptis morio is undoubtedly the most common, found in almost every microregions. Its habitats are mainly short grassy meadows, which are characterized by Festuca species. The species is also present in degraded vineyards, orchards, and in cemeteries. In the valleys of the Keszthely Mts, it lives in sandy and rocky meadows; while it was also found on Molinia meadows along the Kerka River. Anacamptis coriophora is now found in only two places on the bordering areas and marshes. In its original habitat near Batyki it was found only in 1995 with three individuals, and has not been found since. Anacamptis palustris has a western European based distribution, while Anacamptis elegans can be mostly found in southeastern Europe and in Asia Minor; the areas of these two species overlap in the Carpathian Basin. As the habitat requirements of the two species are the same, often these species are found together in the marshes and meadows of valleys of the eastern area, also their hybrids can be found. This phenomenon can well be observed in the habitats of Lake Balaton, where Anacamptis $\times$ timbali regularly blooms. Anacamptis pyramidalis is a common species on dolomite hills, while on the steppes and fallows its range is rather limited.

Four of the seven known taxa of the Ophrys genus were found in the sampling site. Ophrys insectifera has already been mentioned by Borbás in his work. This species today lives only in the dolomite vegetation of the Keszthely Mts, while it also survives under Pinus nigra plantations on the hills of the mountain range. The first observation of Ophrys apifera was in 1989, and after a few years of thematic research, about 50 occurrences are known. The flowering of the species is regular in the remaining ancient steppe habitats, while other locations on fallows are often the results of temporary colonization events. Additionally, several subspecies and form variants of the species were observed. Ophrys sphegodes is much more attached to natural habitats, appeared only once on a disturbed pasture. It colonizes secondary steppes only after the disappearance of different weed species, and after the colonization of the main grasslands (Brachypodium pinnatum, Bromus erectus). Both known occurrences of Ophrys fuciflora are found in the sampled region, which represents the eastern edge of the distribution; the habitats of the species are diverse steppes.

Environmental changes and threats in the sampling area

Climate change in recent decades has also brought some changes in the region's orchid flora. The changed circumstances have losers and winners. The lack of precipitation and the drastic reduction, destruction, and drainage of wetlands resulted significant decline of the orchid species, which have wet habitat needs (Dactylorhiza majalis, D. incarnata, Epipactis palustris). While the latter two sur- 
prisingly appear in vineyards and fallows of the vineyards, Dactylorbiza majalis is now critically endangered in the region. In earlier times, some species could survive at low altitudes only due to the annual high precipitation. Nowadays, the only population of Dactylorbiza sambucina, counting dozens of individuals, disappears, although its 235 metre high habitat seems to have remained unchanged for six years. In the same way, Dactylorbiza viridis has now only one population between 220 and 380 metres in the northern cliff. Goodyera repens, which was reported in Göcsej from acidic soils has not been seen for decades. The winners of the changes in habitats include Ophrys apifera, which was previously not found in the region. Since its discovery in 1995, about half a hundred stable populations have become known. Gymnadenia densiflora is currently known in the country only from this area; this species has a similar preference for habitats as Ophrys apifera has. Due to growing interest among botanists, the number of known species of the genus Epipactis has increased significantly. More and more taxa were discovered in the area of Zala. The high number of Epipactis species is mostly due to the diverse geological structure and different climatic conditions of the area. Many species, including Epipactis nordeniorum described from Austria, E. voethii and E. pontica described in the Pontus Mts in Turkey, and the putatively endemic E. tallosii, also grow in Zala County. Recently, several species new for the country have been discovered in the Keszthely Mts in various habitats, such as E. peitzii s. 1., E. leutei, or $E$. helleborine subsp. latina. Among threatening effects, the intensive cultivation of forests, plowing of grasslands, large-scale drainage of wetlands, peat mining, or intensive use of previously extensively cultivated vineyards are to be mentioned.

Acknowledgements - The author is grateful to Viktor Löki for improving the English of the manuscript.

Összefoglaló: Munkámban Zala megye és a határos területek orchideáit mutatom be. Az eredmények több mint negyed század terepmunkájának összegzését tartalmazzák.

A kezdeti évek random kirándulásait a tervszerü, tematikus kutatás követte. A bejárások jelentős helyszínei a következők voltak: szőlőhegyek (gyümölcsösök, gesztenyések, gyeprefúgiumok), vízfolyások mente (lápok, mocsár- és kaszálórétek, ligeterdők), valamint a természetközeli zonális erdők. A jegyzeteket 2004-től felváltotta a GPS-es adatgyűjtés, mely jelenleg közel 28000 pontot jelent; egy felvett pont egy $3 \mathrm{~m}$-es átmérőjű körön belül egy fajt jelöl (példányszámmal, termőhelylyel, fenológiai állapottal és dátummal). Az adatok bemutatásakor a saját eredmények mellett néhány adatközlő által rendelkezésre bocsátott előfordulás is közlésre kerül.

A kutatás eredményeképp 49 faj, 6 alfaj 26 szín- és formaváltozat, valamint 10 hibrid került elő a vizsgált területen. A korábbi szakirodalomban megjelenteken túl számos új faj jelenlétét sikerült bizonyítani.

Az európai orchideairodalom számos alapvető forrásmunkával gazdagodott az elmúlt években, melyek nagyban segítették az egyes fajok és változatok biztos határozását. Ugyanakkor a fel- 
lendült kutatásoknak köszönhetően számos új taxon került leírásra, melyek egy nemzetség ismert fajszámát jelentősen növelték. Míg a kutatásaim kezdetekor rendelkezésre álló publikációkban mindössze 5 Epipactis faj szerepel, mára számuk 23-ra nőtt. Az előfordulások száma és területi kiterjedése jól jelzi az egyes taxonok helyzetét, jövőbeni kilátásait.

A kutatás időszakában a vizsgált táj rengeteget változott. A tulajdon- és termelési viszonyok alapvető megváltozása és az ezzel párosuló klímaváltozás a természetes élőhelyek csökkenését, a másodlagos, jellegtelen területek növekedését hozta magával. Ez pedig az orchideák életfeltételeit is megváltoztatta. A termőhelyükhöz ragaszkodó fajok állománya a maradék élőhelyekre szükült, ez föképp az erdei fajok esetében jelent problémát. A vizes élőhelyek pusztulását követően egyes fajok olyan helyeken jelentek meg, ahol korábban nem voltak ismertek (pl.: Epipactis palustris, Dactylorhiza incarnata a dombtetői sztyepréteken). A felmelegedés néhány hegyvidéki, a tájban magassági elterjedésének alsó határán élő faj számára végzetessé vált, a Dactylorbiza viride, D. sambucina, Orchis pallens töveit már évek óta nem találjuk korábbi, amúgy háborítatlan termőhelyein. Ugyanakkor a változás nyertese az Ophrys apifera, mely mára félszáz helyet kolonizált. A munka remélhetőleg megfelelő kiindulópontot biztosít az a terület orchideaflórájának további kutatásaihoz, további változások detektálásához és értékeléséhez.

\section{REFERENCES}

BAlogh L. \& ÖRDögh F. (1986): Zala megye földrajzi nevei II. A Keszthelyi járás. - Zalai Gyüjtemény, Zalaegerszeg, $212 \mathrm{pp}$.

BÉcsi Á. (2011): Bázakerettye növényvilága. - manuscript.

Borbás V. (1887): Vasvármegye növényfödrajza és flórája. - Vasmegyei Gazdasági Egyesület, Szombathely, $395 \mathrm{pp}$.

Borbás V. (1900): A Balaton flórája. A Balaton tudományos tanulmányozásának eredményei. - Kilián Frigyes M. K. Egyetemi Könyvtáros Bizománya, Budapest, 431 pp.

CsAPody I. (1982): Védett növényeink. - Gondolat, Budapest, 347 pp.

Delforge P. (2005): Orchids of Europe, North Africa and the Middle East. - A \& C Black, London, $640 \mathrm{pp}$.

Gál L. (ed.) (2006): Gyenesdiás nagyközség monográfiája. Gyenesdiás természeti képe II. Növényvilág. - Gyenesdiás Nagyközség Önkormányzata, Gyenesdiás, pp. 113-149.

GÉRUSz Sz. (2009): Bükkös állományok vizsgálata a Csácsi-erdóben. - manuscript.

Hájek M., Háj Ková P. \& Apostolova I. (2005): Notes on the Bulgarian wetland flora, including new national and regional records. - Phytol. Balcan. 11(2): 173-184.

KÁRolyi Á. \& Pócs, T. (1954): Adatok Délnyugat-Dunántúl növényföldrajzához. - Bot. Közlem. 45: 248-267.

Károlyi Á. \& Pócs T. (1968): Délnyugat-Dunántúl flórája I. - Acta Acad. Paed. Agriensis. 6: $329-390$.

KovÁcs J. A. (2005): Dél-Nyugat-Dunántúl flórája VIII. (Egyszikűek) Károlyi Árpád florisztikai cédulakatalógusa alapján. - Kanitzia 13: 125-275.

Molnár A., Sulyok J. \& Vidéki R. (1995): Vadon élö orchideák. A hazai növényvilág kincsei. Kossuth Kiadó, Budapest, 160 pp.

Molnár Cs., Molnár Zs., Barina Z., Bauer N., Bíró M., Bodonczi L., Csathó A. I., Csiky J., DeÁk Á., Fekete G., Harmos K., Horváth A., Isépy I., Juhász M., Kállayné Szerényi J., Király G., Magos G., Máté A., Mesterházy A., Molnár A., Nagy J., Óvári M., Purger D., Schmidt D., Sramkó G., Szénási V., Szmorad F., Szollát Gy., Tóth T., Vidra T. \& Viró K V. (2008): Vegetation-based landscape regions of Hungary. - Acta Bot. Hung. 50(suppl.): 47-58. https://doi.org/10.1556/ABot.50.2008.Suppl.4 
MolnáR V. A. (ed.) (2011): Magyarország orchideáinak atlasza. - Kossuth Könyvkiadó, Budapest, $504 \mathrm{pp}$.

Molnár V. A., Takács A., Horváth O., E. Vojt kó A., Király G., Sonkoly J. \& Sramkó G. (2012): Herbarium database of Hungarian orchids I. Methodology, dataset, historical aspects and taxa. - Biologia 67: 79-86.

NAGY T. (2012): Az út, mint nyomvonalas létesitmény kettös szerepe a Vári-völgyben. - manuscript.

PAPP L. \& VÉGH J. (1964): Zala megye földrajzi nevei. - Zala megye Tanácsának Végrehajtó Bizottsága, Zalaegerszeg, $737 \mathrm{pp}$.

Soó R. \& JÁvor KA S. (1951): A magyar növényvilág kézikönyve I-II. - Akadémiai Kiadó, Budapest, $582+538 \mathrm{pp}$.

Szabó I. (1987): A Keszthelyi-hegység növényvilágának kutatása. - Bakonyi Term.-tud. Múz. Közlem. 6: 77-89.

SZENCZy I., HUTTER M. \& WieRzBICKI P. (1842): Elenchus plantarum in territorio Keszthelyensi a cl. cl. Szenczy, Hutter et Wierzbicki observatarum, exmissis cryptogamis. - manuscript, Magyar Természettudományi Múzeum, 12 pp.

(submitted: 04.04.2019, accepted: 15.06.2019) 